

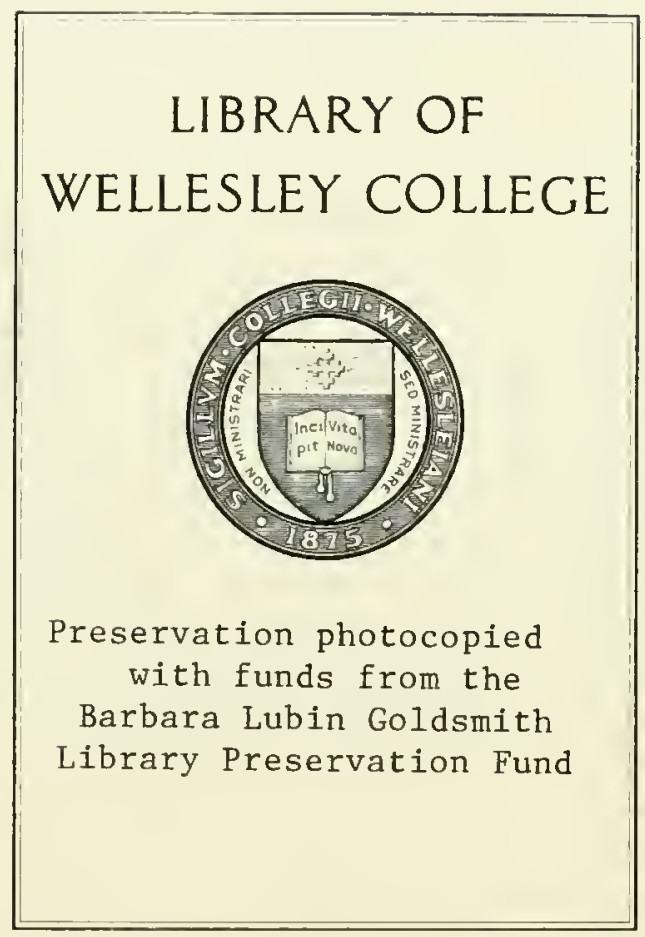






Science

0

11

. C9

$16: 2$

$3-407$

TRANSACIIONS OF THE

CONNECTICUT ACADEMY OF ART'S AND SCIENCES

INCORPORATED A. D. 1799

\section{New Spiders}

\section{from New England}

BY

J. H. EMERTON

PUBLISHED UNDER THE AUSPICES OF

YALE UNIVERSITY

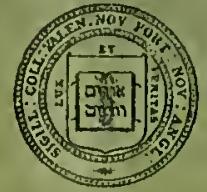

NEW HAVEN, CONNECTICUT

1911 

TRANSACTIONS OF THE

CONNECTICUT AGADEMY OF ARTS AND SCIENCES

INCORFORATED A, I, 1799

\section{New Spiders \\ from New England}

BY

J. H. EMERTON

PUBIISHED UNDER THE AUSPICES OF

YALE UNIVERSITY

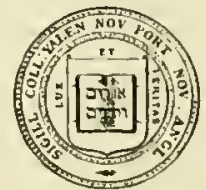

NEW HAVEN, CONNECTICUT I9II 


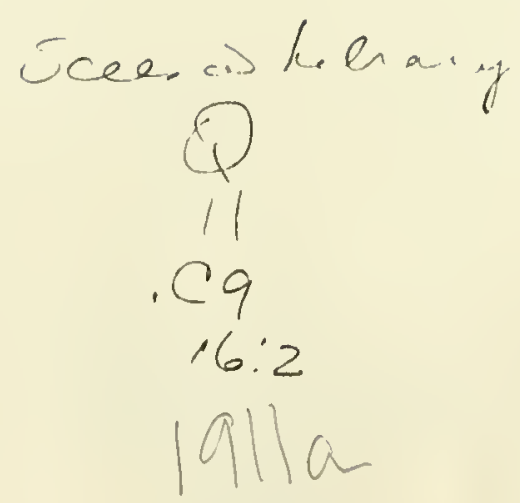

WELMAR: PKINILD BY R, WAGNER S OHN 
New Sididers from New England

nY J. H. EMERTON.

This paper describes 25 new species and 15 described species of spiders found in New England since the completion of the Supplement to the New England Spiders published in the Transactions of the Conn. Acad., Vol. 14, January, 1909. Two of these are European species apparently lately introduced: Teutana grossa, found in a museum basement in company with $T$. triangulosa and Epeira diademata, found at Newport, R. I., and evidently well established aromind the house of the Historical Society and for several blocks along the adjoining street. The two European species of Zilla are now abundant: $Z$. x-motata all over Cape Cod and the Soutl shore of Massachusetts and Rhode Island and Z. atrica on Cape Ann and the adjoining country as far south as Fall River and Newport, but not far inland. Zora spinimana, a European spider, luas been found several times in one locality only, but in a situation where there seems little probability of its being introduced. Four species first described from the Canadian Rocky Mountains have now been found in Northern New England. Of these Linyphia humilis is abundant among the dwarf firs and spruces at a height of 2000 to $4000 \mathrm{ft}$. on Greylock, Mass., Mit. Mansfield and Camel's Hump, Vt., Mit. Washington, N. H., and at the sea level in eastern Maine at Eastport. Pedanostethus fuscus described first from the Rocky Mountains under the name of Steatoda occurs at several places at about $2000 \mathrm{ft}$. elevation around Mlt. IVashington. The other two species are Lycosa çuinaria and L. beanii found at Bangor and on Mt. Desert, Me. Ot the native species, wo were formerly included in others to which they are nearly related, Ceratinella carinata in C. laetabilis and Pisaura brevipes in P. (Ocyale) undata. The two species formerly included in Phrmolithus almrius have been separated and the larger one named $P$. borealis. The systematic relations of several species are doubtful, especially Tmeticus armatus Bks. which has pits in the sides of the head like Lophocarenum and male palpi like Erigone or Gongylidium with long setxe at the base of the tarsus as in Tmeticus longisetosus and flaveolus. Histagonia nasutus resembles H. (exechophysis) palustris Bks. lut has the peculiar character of 
the head cxaggerated. Another species of special interest is Microneta olivacea. The male was described from Mt. Washington in 1882, the female was found by Britcher on Mt. Katahdin in 1901; but the relation between the two was not noticed until the discovery of both sexes in several localities in 1910. The female has a peculiar projection of the front of the head and thickened palpi resembling those of an undeveloped male and an epigynum of the Microneta type of unusual size corresponding to the large palpi of the miale.

\section{List of Now Species.}

Ceratinella sphaerica. " carinata.

Araconcus bispinosus.

Dicymbium pectinatum.

Histagonia nasutus.

Lophocaremun excavatum.

" erenarium.

$"$ andiciliormm.

Timelicus aestivalis. flugellahmm.

" tarsalis.

$"$ entomologious.

" lemuipalpis.
Bathyphantes intricata.

Diplostrla lirewis. theridiformis.

Dictuna terrestris.

Argenna obesa.

Pisuma bripipes.

Partosa muscicola.

Liocramm calcaralum.

Micaria longispinu.

Plorurolithus horealis.

Prosthesima transtersa.

Sittacus striatus.

Described species lately foumd in New England.

Teulana grossa $K$.

Pedanostethus fusca Em.

Lophocarenmm bilobatum Bks. exigumm Bks.

Timeticus armatus Bks.

Grammonola trivitata Bks.

Linyphia humilis Em.

Epeira diademata $\mathrm{Cl}$.
Lally's foxii Marx.

Lycosa quinaria Em.

Lycosa beanii Em.

Phrurolithus mimulus Bks.

formica Bks.

Zora spinimana Snd.

Denaryphante's castaneus Hentz. 


\section{Theridion globosum, Hentz.}

The male of this species is $2 \mathrm{~mm}$. long with the first leg $5 \mathrm{~mm}$. long. The head extends forward a little more than in the female and the front middle eyes are as far from the upper middle pair as they are from each other. The abdomen is round and not as much elevated as in the female; it has a black spot on the hinder half, but the light area around it is not as distinct as in the femalc. There is a black spot in the middle of the under side of the alydomen. Pl. I, fig. 1.

The male palpus has the tarsus prolonged into a slightly curved horn, and opposite this on the outer sicle of the palpus the bulb extencls into a sliarp point curved like the horn, but half as large. Figs. $1 \mathrm{a}, 1 \mathrm{~b}$.

Fitzwilliam, N. H., with female, July 21, 1907. Blue Hills, Milton, Mass., Niss Bryant, June 25, 1904. Cold Spring Harbor, Long Island, N. Y., July $t, 1907$.

\section{Teutana grossa, Koch.}

Female $8 \mathrm{~mm}$. long, cephalothorax $3 \mathrm{~mm}$. The cephalothorax is shaped as in triangulosa, but the sternum is heartshaped and does not extend backward between the fourth coxæ. The cephalothorax and legs are dull ycllow without any markings. The abdomen is jurplish brown with lighter markings forming a half circle near the anterior end and a middle row of triangles. PI. I, fig. 2. On the under side the abdomen is of the same color with fine obligue lighter lines at the sides. The epigynum has a dark semicircle. across it in front, much as in triangulosa. Fig. 2 a.

One female in company with triangulosa in cellar of the building of the Boston Soc. Nat. Hist. A European species probably introduced.

\section{Pedanostethus fuscus.}

Steatoda fusca, Em. Canadian Spiders, Trans. Conn. Acad., 1894.

This species has now been found in the White Mountains in the Carter Notch, Crawford Notch and the Great Gulf of Mt. Washington. It resembles $P$. pumilns but is onc-half larger. In sizc and color it is like Tmeticus brumncus with which it lives. The epigynum is without 
any anterior hard appendage. See Trans. Conn. Acad. 1894. The palpus has the tarsus shaped as in pumilus. At the base of the palpal organ on the inner sicle the process is longer and sharper at both ends than in pumilus. Figures are given of this process in the four species of Pedanostethus. Pl. I, figs. $3,3 \mathrm{a}, 3 \mathrm{~b}, 3 \mathrm{c}$.

\section{Ceratinella sphaerica, new.}

Nales $1 \mathrm{~mm}$. long. Cephalothorax as wide as long and two-thirds as high in front as it is wide. Abdomen round, as wide as long and nearly as high, extending forward over the cephatothorax halt its length. Hard covering of the abdomen extending underneath as far as the pedicel and the spimnerets, and covered as in other species with minute pits and hairs. P'. I, figs. 4, 4a. The color is dull, the cephatothorax and abdomen nearly black, and the legs yellowish gray. The sternum is wicler than it is long and between the fourth coxa as wide as it is in front. The male palpi are as long as the cephalothorax. The patella and tibia are of the same length and the tibia but little widened at the front. The onter process is slightly curved outward and downward. Fig. 4c. The palpal organ is of the usual structure in the genus, with all the parts of moderate size and length. Fig. $4 \mathrm{~b}$.

Two males under leaves in moist woods, Tyngshoro, Mass.

\section{Ceratinella carinata, new.}

Like $C$. laetabilis except in the jalpi of the male. The palpi have the tibia narrower than in lactabilis, not more than twice as wicle as long and the wide black tooth is a fourth smaller. The tarsus has on the outer erlge three dark ridges that from some directions look like spines and between the two onter ridges are a few minute hairs. The whole tarsus is slightly smaller than in lactabilis. All the males found in a bog at Springfield, Mass., and near the Wayside Inn in Sudbury are of this species. In Concord, Mlass., this and latabilis were found together. The tarsus of the male palpus of $C$. laeta has ridges on the outer edge similar to those in carinata. Pl. I, figs. $5,5 \mathrm{a}, 5 \mathrm{~b}, 5 \mathrm{c}$, show the tarsus and tibia of males of this species compared with laetabilis, lacta ant brumea.

Grammonota trivittata, Bkis. Journ. N. Y. Ent. Soc., 1895.

$2 \mathrm{~mm}$. to $2.5 \mathrm{~mm}$. long, more slender than $G$. ornata and with longer legs. The palpi of the male are at long as the cephalothorax, while in ormata they are shorter. The color is generally lighter than in ornato, the heat is lighter than the thorax, while in 
ornata the head is darkest. Pl. I, figs. 6, 6a. The light spots of the abdomen are mited more closely than in onata, and form two serrated longitudinal stripes. The male palpus has the patella and tibia both longer than they are wide, and the whole palpus longer than in ormata. The palpal organ resembles that of ormata, but is slightly smaller. Figs. $6 \mathrm{~b}, 6 \mathrm{c}$.

Salt marshes from Gloucester, Mass. to Long Island N. Y.

Grammonota gigas, Em. Trans. Conn. Acad., 1909.

Erigonoplus gigas, Bks. Canadian Entomologist, 1896.

Plum Island, Mass., Jume 17, 1910, under straw on growing grass at edge of salt marsh. The markings of the abdomen are more uniform than in ornata, the front light spots not much larger than the others. The female has the head slightly raised behind the eyes. The epigynum has the middle depression square instead of narrowed in front as it is in ornata.

\section{Araeoncus bispinosus, new.}

Male $1.5 \mathrm{~mm}$. long. Cephalothorax as wide as long and a little narrowed in front. The top of the head is elevated abruptly with shallow grooves, but without any holes at the sides. PI. I, fig. 7. The sternum is convex and as wide as long. Fig. $7 \mathrm{c}$. The upper middle eyes are farther from the front middle eycs than from each other and are farther back than the posterior lateral eyes. The male palpi have the patella more than twice as long as wide. The tibia is short and widened on the inner side where it has a long, fine spine, slightly curved and extending over the back of the tarsus. Near the base of the spine is a shorter one sharp-pointed and curved inward. Fig. 7 a.

Two males only, Springfield, Mass., Sept. 20, 1909.

Dicymbiunı pectinatum, new.

Male $1.5 \mathrm{~mm}$. long, dull gray, with lighter yellowish legs. The cephalothorax is high in front with the head highest just behind the eyes, PI. I, fig. 8, but without any holes at the side of the head. The upper middle eyes are very little larger than the front middle eyces. The first legs are a little thicker than the others, and the first metatarsus has on the upper side a single row of seven large hairs. Figs. 8, 8a. The male palpi are as long as the cephalothorax. The patella is long, nearly as long as the femur. The tibia is short and wide and liollow on the under side, in the middle of which the tarsus is 
attached. Fig. $8 \mathrm{~d}$. The end of the tibia is obliquely truncated and the outer corner has a small recurved point. Fig. 8c. The tarsus is round and the palpal organ small and simple. The palpus resembles that of Dicymbium gracilipes of Europe.

One male only uncler leaves at Tliree Mile Island, Lake Winnipesauliee, Oct. 10, 1909.

\section{Histagonia nasutus, new.}

Male $2 \mathrm{~mm}$. long. The front of the head extends forward beyond the mandibles and upward as high as the front eyes, covered on the highest part with short hairs directed upward and backward. The head is elevated and the eyes all turned mpward. Pl. 1, figs. 9,9a. Seen from alove the cephalothorax appears pointed in front as in $H$. palustris. The abdomen is oval and the whole body dull gray without markings. The male palpi resemble those of $H$. palustris but the tilia is more simple and the parts slorter and less pointed without the distinct wedge-shape when seen from above in pahustris. The palpal organ is much as in pulustris with the tube shorter and the support longer and more pointed.

One male only with pahustris in dust and leaves waslied up on the shore at Three Mile Island, Lake Winnipesaukee, N. H.

\section{Lophocarenum bilobatum.}

Dicyphus bilobatus, Banks. Canadian Entomologist, 1896.

In size and color this resembles $L$. decemoculatum. The cephalothorax and legs are bright orange and the abdomen bluish black. The cephalothorax is nearly is wide as long, rounded in front and withont the projection over the mandibles which is so distinct in decemoculatum. The hump is divided into two distinct lobes, each oval, and about twice as long as wide. Pl. 11, fig. 1. The holes in the heal are elose behind and a little higher than the upper lateral eyes, tig. $1 \mathrm{a}$, appearing from in front like an additional pair of eyes as in decemoculatum. Behind the two lobes and around their outer sides the cephalothorax is sliglutly elevated. The male palpi are more slender and the palpal organs smaller than in decemoculatum. The tibia has on the upper and inner side a slender, slightly curved hook, extending along the edge of the tarsus more than half its length. Fig. 1. The palpal organ is simple, the tube and a soft conductor arranged as in decenoculatum and florens, but smaller and more slender. Fig. 1 b.

So. Framingham, Mass., from low plants on the edge of a flooded meadow, May 15, 1910. 
Lophocarenum exiguum, Bks. Proc. Phil. Acad., 1892.

Length of male $1.5 \mathrm{~mm}$. Legs pale, but the rest of the body dark; the cephalothorax yellow brown and the abclomen gray. The sternum is clark brown but the coxie as well as the rest of the legs are pale. The head of the male is high and has a narrow vertical hump with the upper niddle eyes on top of it. Pl. II, fig. 2, 2a. There are grooves in the head extending forward over the npper lateral eyes so that the edge ean be seen from in front. Fig. 2 a, 2 c. The female has no trace of the hump. The male palpus has the patella short and the tibia flattened and divided into two branches, the upper branch flat and turned nearly vertical, and the lower branch curved in a flat hook over the back of the tarsus. Figs. $2 \mathrm{a}, 2 \mathrm{~b}$. The upper branch of the tibia is irregularly toothed with a large tooth at the upper and one at the lower cormer. Fig. 2 b.

Woodbridge, near New Haven, Conn. Miss E. B. Bryant in Mus. Comp. Zool. Found by Banks at Ithaca, N. Y.

\section{Lophocarenum excavatum, new.}

Male and female $2 \mathrm{~mm}$. long. Abdomen punctate all over with short seattered hairs in the depressions. In the male there is a thickened shield covering the dorsal half of the abdomen as in Ceratinella. Pl. II, fig. 3. The abdomen and eephalothorax are chestnut brown, except the top of the hump on the head of the male, which is pale like the legs and palpi. In the male the head is divided into two parts by a noteh in front and the upper halt forms a rounded hump carrying in front the upper middle eyes. Figs. 3, 3a. On each side of this hmmp is a deep oval depression. In the female the middle eyes are far apart but there is no trace of the hump. The male palpus has the patella long and the tibia short, with a long process on the upper side encling in a small hook. Figs. 3, 3b. The tarsal hook and the parts of the palpal organ are all small. Fig. $3 \mathrm{~b}$. The epigynum is flat and simple in form. Fig. $3 \mathrm{c}$.

Ipsivich, Aug. 18, 1908, under straw on the edge of the salt marsl.

\section{Lophocarenum arenarium, new.}

Head slightly raised as in simplex and erigonoides. The pits are only a little farther back than the upper middle eyes, and are small and not easily seen. The lower middle eyes are higher than the lower lateral pair. The face below the eyes extends forward and 
is covered with short, stiff, black hairs directed upward. PI. II, ligs. 4, 4a. The first and second legs have similar short, stiff hairs on the under side. On the femur the luairs are clustered at the base and are smaller and in two rows toward the tip. On the tibia they are longer and in eiglit or ten pairs, and on the metatarsus and tarsus they are finer and more like ordinary liairs. The first and second legs are slightly thicker than the others. The cephalothorax is as wide as it is long. The sternum is as wide as long, and extends between the fourth legs where it is as wile as one of the coxa. The male palpi are short with the patella about twice as long as wide and widened at the end. The tibia is not widened laterally lout extends upward over the tarsus, ending in a slightly curved tip on which is a small incurved point. Figs. 4, 4l). The tarsal hook is simple in form, and its base follows the curve of the tilia. The tube of the palpal organ is long and slender, and makes one turn around the end of the bulb, supported at the end by a thin appendage half its own length. Fig. $4 \mathrm{~b}$.

The female is the same size and color as the male and has the head a little elevated, lut no unusual arrangement of hairs on the head or front legs. The epigynum is short and wide, showing through the skin round recejtacles more than twice their diameter apart. lig. $4 \mathrm{c}$.

One male, Ipswich, Mass., Nay 12, 1908 under straw at Lakeman's Beach. Males and females on salt marsh at Oak Island, Ly'nn, Mass.

Lophocarenum domiciliorum, new.

From cellar of Boston Society of Natural History, November, 1910. The head is only slightly elevated behind the eyes. The upper row of eyes, seen from above, is nearly straight. At the sides of the head beginning just behind the upper lateral eyes are deep grooves extending lackward half the length of the head, with shallow and pointed pits near the anterior end. Pl. II, figs. 5, 5a.

The male palpus las the patella as long as wide and the tibia a little longer, widened at the anterior end, with a long, sharp point on the inner side. The tarsus is oval and the palpal organ small and simple. Figs. $5 \mathrm{~b}, 5 \mathrm{c}$.

During the autumn flights great numbers of small spiders are blown into Boston and alight on the fences of the common and the streets west of it. 'This spider probably' came into the city' in this way. 


\section{Lophocarenum flagellatum, new.}

Male a little over $t \mathrm{~mm}$. long. The ceplaalothorax high in front and highest behind the eyes. At the sides of the hump are grooves with a rombl pit at the anterior end. The grooves are umusually far behind the eyes and when seen from above resemble those of L. minutum; the head, however, is much higher than in that species. Pl. II, figs. 6, 6b. The male palpi also resemble those of minutum. Their patella and tibia are both short but the tibia shortest. The tibia is widened at the end and has a long, slender process extending over the outer sicle of the tarsus nearly its whole length, and slightly hooked at the tip. Fig. 6.

One male from Seal Harbor, Mit. Desert, Ne., July 1, 1909.

\section{Lophocarenum florens and decemoculatum.}

Several females found with males in the early summer of 1909 show the differences between these two species which in general appearance closely resemble each other. The epigymum of florens is alreadly well figured in N.E. Therididx, Trans. Conn. Aead., 1882. That of decemoculatum is shown in a new figure, Pl. II, fig. $7 \mathrm{~b}$. The eyes of florens are farther apart than those of dccmoculatum and the upper middle eyes are higher and farther from the front mildle pair than they are from each other. In decemoculatum the midlle eyes nearly form a square, the upper pair being only a little farther apart than the front pair. ligs. 7,7 a.

Lophocarenum (Tmeticus) armatum Bks. Proc. Ent. Soc. of Wasl.ington, Feb. 1, 1906.

Male 4 mm. long. Cephalothorax and legs orange yellow, abdomen bluish gray. The head is slightly elevated and there is a shallow groove and a small round hole close hehind the lateral eyes. I'l. II, Figs. 8, 8a. The ipper midlle cyes are fasther from the front eyes than from each other. The mandibles are large and with several large spines. In front and showing from above is a large pointed tooth pointing downwarl. On the inner side of the mandible, near the middle, is a large tooth and nearer the base two others, and there are several small teeth and processes around these larger ones. Figs. $8,8 \mathrm{a}, 8 \mathrm{~b}$. The maxillæ are wide and project sidewise beyond the sternum. Their front edge has a double tooth at the onter corner. The stermum is widest in front, where it is nearly as wile as long. At the hinder end it has a narrow projection between the fourth coxie. ling. $8 \mathrm{~b}$. The palpi are long and resemble those of Erigone having a similar tooth directed downward on the patella. 
Fig. $8 \mathrm{f}$. The tibia is widened at the end as in Erigone and Gongylidium. At the base of the tarsus are three stifl bristles like those of Tmeticus longisctosus. Fig. $8 \mathrm{e}$.

The female is $3 \mathrm{~mm}$. long, colored as in the male, but paler. The eyes have a similar arrangement, but are not elevated above the ceplablothorax. The mandibles are large but without unusual processes and have five teeth on the front of the claw groove. 'The maxillae are wide and projeet a little beyond the sternum. 'The sternum is wicle in front, widest between the first and second legs, and projects backward letween the fourth coxæ. The epigynum is shown in fing. $8 \mathrm{~d}$.

White Mountains, N. H., near the Crawford Notch, sifted from leaves, Sept. 25, 1908. Banks deserilsed it from Manitolia.

\section{Tmeticus aestivalis, new.}

$1.5 \mathrm{~mm}$. long. Cephatothorax nearly as wide as long and the abdomen narrower and oval. The sternum is as wide in front as it is long, and varies in shaje. In some males it is almost triangular, with the sides straight and the widest part just behind the first legs: but usually the sides are slightly curved to the fourth coxre, where the sternum is very narrow and extends between them. The male palpus has the tiljia nearly as wide as long and divided at the front end, the outer brancl curving ontward. The tarsal hook is large and grooved on the outer side with two teeth at the end, the outer one largest and curved toward the other. At the end of the palpal urgan is a black forked appendage bent toward the bull and pointed forward and outward. Pl. Ill, figs. 1, $1 \mathrm{a}, 1 \mathrm{~b}$.

The female is as large as the male, with the cephalothorax not (puite as wide. The epigynum appears without magnifying as two parallel dark stripes, at the anterior end of which the small romal receptacles show through the skin. Fig. $t \mathrm{c}$.

Mt. Tolyy and Holden, Mass., in June under leaves.

\section{Tuneticus tarsalis, new.}

$2 \mathrm{~mm}$. long. Cephalothorax nearly as wide as long, with the whole anterior half elevatel. Pl. III, fig. 2. The eyes are slightly raised above the rest of the head and the front of the cephalothorax from the eyes to the mandilses is nearly vertical. The male palpi are as long as the ceplualothorax, with the tarsus and palpal organ large and rounded, and a very long tube thick at the base and coiled entirely around the tarsus. Fig. 2a. The tibia is short and small, showing above two short teeth. The tarsal hook 
is bent at a sharp angle, as in $T$. debilis. The onter edge of the tarsus which is without hairs and separated flom the rest by a sharp ridge lias a wide rounded lobe in front of the tarsal hook. lig. $2 \mathrm{~b}$.

Fall River, Mass., Mt. Mansfield, Vt., Crawford Notch, N.H.

Tmeticus entomologicus, new.

Only $1 \mathrm{~mm}$. long and dull gray. The cephalothorax is one-fouth longer than wide and the head low, and a little narrowed. The front row of eyes is one-fouth shorter than the upper row, the front eyes are close together and the middle eyes only half the diameter of the lateral. The male palpi have the tibia elongated on the upper side and truncate at the end. The tarsal hook is curved in a half circle and simple in form. Pl. 111, fig. 3. The tarsus is short and round and the palpal organ large with a short tube and two large processes.

lpswich, L. R. Reynolds, and Tyugsboro, Mass, F. Blanchard, under leaves in Nay and June.

Tmeticus tenuipalpis, new.

Males and females $3 \mathrm{~mm}$. long. Abdomen ligh and round and marked as in $T$. probatus with light spots in pairs. The legs and palpi are long and slender. The general color is dnll gray without markings except the spots on the abdomen. The mandibles are rery large in both sexes. In the male the mandible has on the front and outer side a row of five stout teetl, smallest toward the head. Pl. III, figs. 4, $4 \mathrm{~b}$. On the under and inner side are two rows of long teeth, four in the outer and five in the inner row, between which the claw is folded. Fig. 4 a. The maxillæ are long and wide, with blunt teeth at the sides, extending beyond the sternum. The trochanter has also a short tooth on the uncler side. The male palpi are unusually slender and nearly twice as long as the ceplalothorax. The tibia is slightly widened at the end with short teeth around it. The tarsus is more than twice as long as wicle and the palpal organ occupies only the basal half. The tarsal hook is short and without any prominent points or hooks. Figs. $4 \mathrm{c}, 4 \mathrm{~d}$.

The female has the same rows of spines on the mandibles as the male, but all much smaller. The epigyum is very simple. Fig. $4 \mathrm{e}$.

Ipswich, under straw on the edge of the salt marsh, August 1908 and 1909. 
Microneta olivacea, Emerton. N. E. Therididae, Trans. Comn. Acad. 1882.

The male is $2 \mathrm{~mm}$. long, the cephalothorax $1 \mathrm{~mm}$. The cephalothorax is as wide as long and wider than the abdomen. In front it extends forward slightly beyond the eyes and beyond the mandibles. The eye area is a little elevated. PI. III, fig. 5, 5 b. The mandibles are narrowed at the ends and have one very small tooth near the imer angle. The male palpi are of the microneta type but unusually large. The tarsus is angular and las a small spur at the lase. Figs. 5, 5a. The tarsal hook is wide and flat with a tooth at the end and a wider one at the angle.

The female is as long as the male but has the cephatothorax a fourth longer than wide. Fig. $5 \mathrm{~g}$. The color is lighter than in the male and yellowish brown rather than gray. The ceplialothorax extends forward beyond the eyes farther than in the male and projects distinctly beyond the mandilbles. Fig. $5 \mathrm{c}$. The mandibles are slightly curved forward at the ends as they are in the male, but are not nuch narrowed, and the single tooth is large. Fig. $5 f$. The palpi have the tarsus thickened in the middle so that it appears like that of an immature male. Figs. $5 d, 5 h$. The epigynum is folded and resembles that of other Nicroneta and Bathyphantes. Figs. $5 \mathrm{i}, 5 \mathrm{k}$.

The female was found by the late H. C. Britcher on Mt. Katahdin, Me., in 1901, and has since been found with males on Greylock and Mit. Mansfield.

Three females found with two males at Norcross, Me. June 30, 1910 , resemble those from other places except that the palpi are not swelled at the end. Fig. 5 e. The males agree with those from other places.

\section{Bathyphantes theridiformis, new.}

Cephalothorax $1 \mathrm{~mm}$. long. Whole body $2 \mathrm{~mm}$. long in male and $3 \mathrm{~mm}$, in female. Color pale with gray markings resembling Theridion sexpunctatum. The cephalothorax has a wide middle dark stripe as wide in front as the eyes and tapering slightly backward. There is a dark line along the sides of the cephatothorax nearly to the eyes. The legs are slightly gray ou the ends and. middle of each joint. The abdomen has on the back a dark mark wver the dorsal vessel and a series of pairs of irregular dark spots more or less united with spots along the sides and with eacl other.

On the under side the coxa and mouth parts are pale and the sternum gray. The ablomen is gray, lighter in the middle, and 
darker along the sides, the markings varying in individuals and sometimes broken into irregular spots.

The male palpi have the tarsus with a small process at the base on the upper side. The tarsal hook is curved outward at the end where it has two points, the distal one much the longer. Fig. 6a. The mandibles of the male are turned apart from the middie, where two of the teeth aloner their edge are much larger than the others. Fig. $6 \mathrm{~b}$.

The epigynum is short and wide, the outer fold in two lateral lobes, with a small middle one. Fig. $6 \mathrm{c}$.

Jackson, N. H., June 1, 1910.

\section{Bathyphantes intricata, new.}

$3 \mathrm{~mm}$. long and pale, without any markings. Cephalothorax and legs yellowish and the abdomen gray. The legs long and slender, the front pair $8 \mathrm{~mm}$. long. The male palpi have the tibia and patella short and of the usual form, without processes, but the tarsus and its appendages are extremely complicated, as best shown in the figures. The tarsus has a sharp angle on the upper side and a process at the base and both these are elongated into sharp, curved teeth. Pl. III, figs. 7, 7d. The tarsal hook is hard to describe. It has all the curves and angles found in this genus and all exaggerated into teeth and ridges.

Three Mile Island, Oct. 20, 1909.

\section{Diplostyla brevis.}

Like nigrina in size and color, varying in length from $2 \mathrm{~mm}$. to $3.5 \mathrm{~mm}$. and in color from pale to dark gray, almost black. As in nigrina the markings of the back of the abdomen, especially near the front end, may he small gray spots in pairs on a pale groumd or they may be pale spots in a genesal dark gray. On the under side this species is generally lighter than nigrina, having two pale stripes sometimes extending the whole length or sometimes only partway backward from the epigynum with the space between the stripes, in some individuals, nearly as pale as the stripes themselves.

The epigynum has the two median finger-like appendages not more than half as long as in nigrina. Pl. 1V, fig. $1 \mathrm{~b}$. The male palpi have the tarsus a little shorter and less angular than in nigrima. Figs. 1, 1 a. The tarsal hook has a blunt point not widened at the tip as in nigrina. Fig. 1. The palpal organ has the middle process on the under side not straight as it is in migrina, but curved 
around the base of the tube, and usually pointed at the tip with a tooth on the outer side; but this varies in different individuals. Fig. 1 a.

Under leaves at all seasons. Tyngshoro, Cambridge, Mt. Mansfield, White Mountinins. Flying from fences, Readville, Mass., in November.

Linyphia humilis, Em. Canadian Spiders, Trans. Conn. Acad. Vol. IX, 1894.

This speeies first deseribed from the Rocky Mountains of Canada las now been found on the upper part of the Green Mountains, from Mt. Mansfield, Vermont, to Greylock, Mass., on Mlt. Willard in the White Monntains, and at the sea level at Eastport and Machias,

- Me. It lives in the low lirs and spruces that eover the tops of Greylock and Mansfield, and las not been found there below 2000 feet; and from 2000 to 4000 feet on Mt. Washington, most abundant in the dwarf trees along the road near the Half-way Honse, and becoming seareer downward as far as the prath to Hermit Lake. Found in the Great Gulf near the Appalachian Club camps. In Maine it lives also where the forest consists largely of stunted spruces in eompany with Theridion zelotypum. Botll miles and females are found in the Green Momntains in great abundance in the middle of June, and the young in September. The shape of the abdomen of the female is slightly pointed behind and high in the middle. Pl. IV, fig. 2c. The dorsal marking is divided by two notehes at the sides into three parts, the middle part much smaller than the other two. Fig. 21). The colors resemble communis, for which it may be sometimes mistaken. In the male the colors are much brighter, the cephalothorax and legs light orange and the abdomen brown. The head of the male is as high as it is wide and black between the eyes. The male palpi resemble those of L. marginata and have the tarsal hook showing plainly from above, curved in a half circle with the end slightly widened. Fig. 2a. The epigynum is shown in fig. $2 \mathrm{~d}$. See also figures in Trans. Conn. Acad. Vol. IX.

\section{Epeira diademata, $\mathrm{Cl}$.}

Newport, R. I. On window frames, fences and vines around the building of the Historical Society and fences of neighboring gardens on Touru Street, Sept. 20, 1910. One adult of under fence cap. Large females with nest above the web. A common European speeies reported from Vancouver, Wisconsin and Newfoundland, but now found far the first time in New England. 
Zilla x-notata, Z. atrica.

Z. x-notata described in Trans. Conn. Acad., Vol. VI, 1884 from Woods Hole, Mass. is abundant at Provincetown, on wharves, bams and houses near the shore; also at Wellflect and Harwich and at Newport, R. I., on the street fences; New Bedford on wharves and fish houses; and Fall River on boat houses, but in small numbers. None were found at Dighton and Taunton. On the same street at Newport where Z. $x$-notata is found on the fences $Z$. atrica occurs in hedges. It is also common at Fall River on hedges, fences and garden shrubs. At Taunton this species was absent, as well as $x \cdot n o t a t a$.

Dictyna terrestris, new.

$2 \mathrm{~mm}$. long and resembling closely $D$. volupis. The front middle eyes are farther forward than in iolupis, so that the middle eye area is longer than wide. Pl. IV, figs. $3 \mathrm{c}, 3 \mathrm{~d}$. The male palpus has the tibia short, not longer than wide, except on the onter side. The tarsus and palpal organ are very large and both curved downward more than in volupis. Fig. $3 \mathrm{~b}$. The mandibles of the male are not turned forward at the ends as much as in rolupis.

Three Mile Island, N. H., June 1. Plum Island, Nass., June 17.

Argenna obesa, new.

Female 2.5 to $3 \mathrm{~mm}$. long. Cephalothorax $1 \mathrm{~mm}$. The whole body pale, cephalothorax a little darker than the abdomen. The linder half of the abdomen indistinctly marked with angular spots. Pl. IV, fig. 4 a. The abdomen is oval and longer than the cephalothorax. The head is wide and but little elevated. The front middle eyes are smallest, but only a little smaller than the upper middle pair, and the front eyes form a nearly straight row at equal distances from each other. The sternum is nearly as wide as long, and with a blunt point behind that extends backward between the fourth coxæ. The cribellum is small and undivided. Fig. 4. The fourth metatarsus is slightly curved and the calamistrum extends about half its length.

The male differs from the female in the smaller abdomen and longer and larger front legs. The male palpi have both the patella and tibia short and wide. The tarsus is nearly as wide as long and pointed at the end. The tibia has a wide process that extends forward along the outer sicle of the tarsus and against this lies a wide pointed appendage of the palpal organ supporting the end of the tube, somewhat as in Dictyna. Figs. $4 \mathrm{c}, 4 \mathrm{~d}, 4 \mathrm{e}$.

'Trans. Conn. Acai., Vol. XVI. 
Abundant under straw on the edge of salt marslıes at lpswich and Plum Island. Adult males in June and July, Cold Spring Harbor, Long Island, N. Y'., Mliss Bryant.

Lathys foxii $=$ Prodalia foxii, Marx. Ent. Soc. Washington, 1891.

$2 \mathrm{~mm}$. long. Pale, with the cephatothorax a little darker than the abdomen. Abdomen marlied with a middle row of brown angular marks that in some individuats join a row of spots along the sides. PI. IV, fig. 5. In the male the clark marks are wider so that there appear to be light marks on a darker ground. The front row of eyes is shorter than the upper row and the front middle eyes much smaller than the others. Pl. IV, fig. 5e. The sternum is nearly as wide as long, with a blunt point behind which extends between the fourth coxae. The cribellum is small and molivided. Fig. 5 a.

The male palpi have the patella and tibia both very short. The patella is widened at the end so that seen from above it is twice as wide as at the base. The tibia is also widened at the end and has a groove above in which rests the end of the tube of the palpal organ, which extends along the outer side of the tarsus and turns inward and npward between tarsus and tibia. Fig. $5 \mathrm{~d}$.

Under leaves at all times in summer and autumu. Males from Hollis, Me., June 12. Females from Old Orchard Beach, Me., Holden, Carlisle, Huntington, WVilliamstown, Nass, Kent, Conn.

Pisaura brevipes, new.

A smaller and dark form of Pisaura formerly placed with $P$. undata. It is one-sixth smaller than undata and dark brown even when small and freshly molted, and the middle stripe has nearly straight sides, both on cephalothorax and abdomen, with a bright white line along its edges. The sides of cephalothorax and abdomen are dark brown. The legs are brown without rings. The first leg is shorter than the fourth and without the femur is shorter than the body, while in $P$. unduta the first leg without the femur and patella is as long as the body. Pl. IV, figs. $6,6 \mathrm{~b}$. The epigynum is slightly shorter and rounder than in undata. Figs. $6 \mathrm{a}, 6 \mathrm{c}$.

Females from Mt. Ton, July, 1873, So. Framingham, May, 1910.

Lycosa quinaria, Em. Canadian Spiders, Trans. Comn. Acad., Vol. IX, 1894.

The male is $8 \mathrm{~mm}$. long, the ceplatothorax $5 \mathrm{~mm}$. long, the fourth leg $14 \mathrm{~mm}$. and the first leg $13 \mathrm{~mm}$. The cephalothorax shows no markings in alcohol, and the legs have no spots or rings, but are irregularly striped lengthwise as in Pardosa glacialis. The male 
palpi are long and the tibia as long as the tarsus. The abdomen is gray with a white micldle stripe more than half its length, continuing to the end in a row of spots. At the sides are similar spots in irregular rows. Pl. V. figs. 1, 1 a.

Nale in sphagnum bog, Bangor, Nle., June 29, 1910. Female from Laggan in the Rocky Mountains in Canada. See Trans. Conn. Acad,, Vol. 1X.

Lycosa beanii, En. Canadian Spiders, Trans. Conn. Acad., Vol. IX, 1894.

This species has the general appearance of fiondicola. The middle stripe of the cephalothorax is straight at the sides and narrowed from the eyes backward. The femora are marked with indistinct rings and there are traces of rings on the other joints. The under side is somewhat lighter than the back and has no black spots or stripes. The epigynum is well shown in the figure in the paper on Canadian spiders.

Seal Harbor, Nlt. Desert, Me., July 1, 1909.

Pardosa muscieola, new.

The male of this species has been confounded with uncata and the female with glacialis. The markings are much like glacialis, with the middle stripe of the cephalothorax more distinctly divided into three at the anterior end. The lance-shaped spot at the front end of the abdomen is equally distinct in both. The femora of muscicola, however, are marked with four distinct but somewhat broken rings resembling the femora of tachypoda and uncata rather than glacialis. Pl. V, fig. 2. The epigynum is wide as in glacialis but the anterior pit is single and the middle lobe straight with parallel sides in the posterior half. Fig. $2 \mathrm{c}$. The male is rather lighter colored than that of glacialis and the tarsus and tibia of the male palpus are not black as in that species but colored as in uncata. The basal process of the palpal organ is shaped as in moata but the long branch is longer and extends entirely across the tarsus, ending in a slightly curved blunt point. Fig. $2 \mathrm{a}, 2 \mathrm{~b}$.

This species lives with glacialis, meata and taclypola on the moss of the upper part of the Green Mountains and White Mountains and in Labrador and Newfoundland.

Pirata montanus, Emerton. Trans, Comı. Acad., Vol. VI, 1885.

The female only is described in N. E. Lycosida, Trans. Conn? Acad., 1885. The male resembles the female in size and markings 
but has greater contrasts in colors, and the legs marked with black, It is $5 \mathrm{~mm}$. long and the cephalothorax $3 \mathrm{~mm}$. The eyes as in the female extend over nearly the whole width of the head and the two upper pairs are nearly as large and conspicuons as in Pardosa. The femora of legs 1 and 2 are black and the other femora have black spots near the end. The cephalothorax is black with the usual light midule stripe divided in front into three, and extending forward between the eyes. Fig. V, fig. 3. The ablomen is gray, tuming a little reddish in alcohol. It has a distinct light and clark pattern consisting of the usual pointed middle mark in front, and a series of bright white spots of hairs and narrow white marks along the sides toward the front, varying in lifferent individuals. The front of the liead and mandibles are black and the under side of the body gray, with a narrow light line on the sternum as in the female. The male palpi are very simple, much as in $I$ '. minuta. Fig. 3a. The basal part of the palpal organ has a flat border that extends forward, nearly covering the short tube and a thin appendage of variable shape near the onter end of the tarsus.

Males and females from Mt. Toby in the central part of Massachusetts, June 12, 1902. Mt. Everett, Mass. Ithica, N. Y.

\section{Liocranum calcaratum, new.}

Both sexes $2.5 \mathrm{~mm}$. long. Cephalothorax slightly longer in the male than in the female. The cephahothorax and legs are pale yellow brown, the ceplablothorax sometimes brighter and redder than the legs. The abdomen is short, oval, and pale, with gray markings, - a middle stripe extending from the front to the middle and four or five transverse stripes, the second and sometimes the first comected with the middle stripe. Pl. V, figs. 4, 4c. Legs 1 and 2 have five pairs of long spines under the tibia and three pairs under the metatarsus in botl sexes. Fig. $4 \mathrm{~b}$. The head is narrowed toward the front. The eyes are in two rows, nearly parallel, the front row shortest with the middle eyes much smaller than the l.teral. The upper row of eyes is slightly curved downward at the cols and the eyes are of the same size and equal distances apart.

The male palpus has the tibia half longer than wide with a short process curved forward on the midlle of the outer side. The tarsus is nearly as wide as long and pointed at the end. The tube of the palpal organ is short and has opposite to it a supporting process about the same size and shaje. Figs. $4 \mathrm{e}, 4 \mathrm{f}$.

Females, Crawford Notch, Sept. 20, Great Gulf of Mt. Washington, Aug. 1. Miles, Jaclison, N.H. June 1, Kátalıdin, Me. July 4. 
Zora spininana, Snd.

$5 \mathrm{~mm}$. long, cephalothorax $2 \mathrm{~mm}$. long and $1.5 \mathrm{~mm}$. wide. The cephalothorax is narrowed in front where it is less than $1 \mathrm{~mm}$. wicle. The eyes are all nearly of the same size, the front row slightly curved backward, and the upper row strongly curved as in Dolomedes. The color is pale with distinct dark brown stripes and spots. The cephalothorax has two dark stripes extending straight backivard from the lateral eyes and two less definite stripes along the edges. The aldomen has two stripes made up of irregular spots a little farther apart than the stripes of the ceplualothorax, and between these two rows of smaller spots converging hehind. Pl. V, fig. 5. On the under side the whole body is pale with scattered dark spots. The under pair of spinnerets have a brown stripe on the onter sicle. The legs are spotted and have a dark ring at the end of the metatarsus, which in the first legs covers nearly the whole joint. The tibia of the first leg is thickened in the middle and has mnderneath two rows of spines 7 on the outer and 8 on the inner sile. Fig. 5b. The metatarsus of the first legr has underneath three pairs of long spines. The second leg has the same thickening in a less degree and similar, but smaller spines. The ejigynum has two indistinct openings in front between and behind which a pair of curved tubes and large round receptacles show through the skin. Fig. 5 a.

Tyngsboro, Mlass. under leaves, mature female, Oct. 16 and immature female in January. A common species in Europe.

Micaria longispina, new.

Male $2.5 \mathrm{~mm}$. long, resembling in form and color $M$. gentilis, but smaller than the usual size of that species. The male palpus has the tibia and patella both short, together as long as the tarsus. The tibia has a long process on the outer side, turned obliquely upward along the elge of the tarsus. Pl. V, figs. $6,6 \mathrm{a}, 6 \mathrm{~b}$.

Ellisville, Plymouth, Mass., May 10.

Phrurolithus formica, Banks. Journal N. Y. Ent. Soc., 1895.

Found only in nests of the ant Cremastogaster lineolatn. Males and females are $3 \mathrm{~mm}$. long, in life clark gray, turning to brown in alcohol. Pl. VI, fig. 1. The legs are a little paler and the alsdomen a little darker than the general color. The abdomen has a hard shining shield covering the whole upper surface. The front half of the under side of the abdomen is pale, the spot varying in size in different individuals. The epigynum shows externally a large 
dark brown area, widest behind and nearly square, with rounded corners, behind which the receptacles show indistinctly through the skin. Fig. 1 b. Smaller and apparently younger females have the epigynum more distinct without the opaque brown area. Fig. $1 \mathrm{c}$. The male palpi are large and of characteristic form. Figs. $1 \mathrm{~d}, 1 \mathrm{c}$. The femur has a knoh-shaped process on the middle of the under side. The process on the outer side of the tibia is short and wide with a long pointed tooth on the upper corner. Figs. $1 \mathrm{~d}$, 1 e. On the inner sicle of the tibia is a large blunt tooth. The palpal organ has a large thick bulb with a long slender tulse turned inward toward the tip of the tarsus.

Forest Hills, Boston, Mass., W. M. Wheeler, Ty'ngsboro, Mass., F. Blanclaad. Found by Banks on Long Island, N. Y.

In the spring when the ants come up and rest in large numbers under stones over their burrows, the spiders are found among them. If not frightened they move slowly ahout like the ants and disappear under ground. If frightened they move much more rapidly than the ants and down into the nest or out into the surrounding grass.

Phrurolithus minutus Bks. Ithaca Spiders, Proc. Phil. Acad., 1892.

Nale $2 \mathrm{~mm}$. long. Aldomen covered with a hard shiny plate and strongly iridescent. Cephatothorax with a narrow light band extending back from the eyes to the dorsal groove behind this widening into a nearly square spot. Pl. V1, fig. 2. The legs are pale except the first pair, which have the tibia black with a white tip and the patella and end of the femur also black, and the second pair which have less distinctly the same markings. The palpi are lark but not black. The tibia of the male palpus has on the outer side a long slender process divided at the end into a short, square lower tooth and a long slender, sickle-slaped upper tooth. The tibia is longer than wide and the outer process starts from its basizl half. Figs. $2 \mathrm{a}, 2 \mathrm{~b}$. On the mnder and inner sile of the tilia is a short, blunt tooth directed forward.

Tyngsboro, Apr. 5, 1909, in open field under straw. One adult mate and several immature males and females.

\section{Phrurolithus borealis.}

P. alarius (in part) Em. Trans. Conn. Acad., 1890.

Male 2 to $2.5 \mathrm{~mm}$. long. Cephalothorax light in the middle aud dark at the sides without any defued markings. Abdomen dark and iridescent with traces of a pattern on the hinder half. Legs 3 and 4 pale without any spots. Leg 1 has the tibia black with 
a white tip and leg 2 has the same colors less strongly marked. The patella and end of the femur of leg 1 are also dark colored. The male palpus is clark colored its whole length. The tibia is as wide as long and has on the outer side, starting in the midelle, a long process that widens toward the end where it is truncated obliquely and has on the upper corner a short, slightly curved tooth turned inward. Pl. V1. fig. 3, 3a.

The female is a little larger than the male, with the abdomen larger and less iridescent and with the hinder half marked with light and dark chevrons. The front lialf lias the markings alosent or indistinct and is sometimes gray and sometimes paler than the rest of the back. The epigymum has the receptacles twice their diameter apart. Under side of abdomen pale or with two faint longitudinal lines.

New Haven, Comn., 'Tyngsboro, Nass., Three Mile Island, Lake Wimnipesaukee, N.H., Crawford Notch.

Phrurolithus alarius, Hentz.

Phrurolithus palustris Bks. Ithaca Spiders, Proc. Pliil. Acad. 1892. P. alarius (in part) Em. Trans. Com. Acad. 1890.

This species and borealis were included under the name $P$. alarius Hentz in New England Drossidæ, etc. in Trans. Conn. Acad. 1890. Male and female 2 to $2.5 \mathrm{~mm}$. long. The cephalothorax is pale with a black line along the edges and two dark bands extending back from the eyes and nearly meeting behind. The abdomen is marked by short lines and chevrous more or less broken into spots, especially in the female. Legs 1 and 2 have the tibia marked with black and white and legs 3 and 4 have the joints tipped with gray and a gray mark in the middle of the tibia. In pale individuals the legs are sometimes without markings, even the dark color of tibia 1 being almost absent. In very dark males the bands of the cephalothorax may be united with the black edges and the abdomen may have the markings covered with gray so as to be very indistinct. The male palpus PI. VI, figs. 4,4 a, has the process of the tibia tapering toward the point and curved inward as figured in Trans. Conn. Acad. 1890, Pl. VI, fig. $5 \mathrm{e}$ and $5 \mathrm{~g}$. The epigynum has the receptacles not more than their diameter apart. The under side of the abdomen has usually two gray spots near the middle, one just in front of the spinnerets and others along the sides.

Around Boston Mass, Hollis, Mle, Lake Wimuipesaukee, N. H., south to No. Carolina. 
Prosthesima rufula Bks. Phil. Acad. 1892.

This is the only brown species found in New England, the others all being black or gray. A new figure is given of the male palpus. showing better the form of the palpal organ than the one in Trans. Comn. Acad. 1909, Pl. V, fig. 7. The peculiar form of the tibial hook is correct in both figures, but the tube of the palpal organ is slender and does not extend the whole length of the outer side of the tarsus.

Prosthesima depressa Em. Conn. Trans. Acad., Vol. IlI, 1890.

Only the female was described in 1890. The males are $5 \mathrm{~mm}$. long and resemble the female. The general color is black but the tarsus and metatarsus of legs 1 and 2 are pale, contrasting strongly with the black of the other joints. The legs 3 and 4 are pale with darker color toward the ends of the joints, nearly covering the tibia. The male palpi have the tarsus more pointed than in atra, with the tube of the palpal organ directed toward the tip. Pl. V, fig. $8 \mathrm{c}$. The tibia has a process on the outer side that varies in form. In some individuals it is sharply pointed, as long as the diameter of the tarsus, and nearly straight; in others it is of the same length and curved, while in others it is short and rounded at the end and curved nearly at a right angle. Figs. 8, $8 \mathrm{a}, 8 \mathrm{~b}$. All these forms of the tibia have been found in specimens collected in the same place at the same time.

Blue Hilts, Milton, near Boston, Mass., Three Mile Island N. H.

\section{Prosthesima transversa, new.}

Nale $5 \mathrm{~mm}$. long. Two specimens dark-colored and one light, apparently lately molted, but neither showing the contrast between light and darks markings which is conspicuous in depressa. The palpi have the tarsus larger than in depressa and the tibia thicker, with the process straight and the tip flattened and rounded and not much curved. Pl. V, fig. 9. The palpal organ is distinctly different from that of the other species, the tube turns forward and ends in the notch at the tip of the tarsus as usual, but at its base begins a slender process nearly as long as the tube which crosses it to the outer edge of the tarsus. The basal processses of the bulb differ slightly in the different individuals, but in all are longer and more slender than in depressa, Figs. $9 \mathrm{a}, 9 \mathrm{~b}$.

Blue Hills and Middleboro, Mass., New Haven, Conn. 
Dentryphantes castaneus, (Hentz), Peckham. Revision of the Attida of North America, Trans. Wis. Acad., 1909.

Female $6 \mathrm{~mm}$. long. Cephalothorax $3 \mathrm{~mm}$. The ccphalothorax is covercd with short gray hairs but in alcohol the whole front half appears black and the hinder laalf brown. The abdomen is brown with a white stripe around the front. There are fine waving black lines ruming irregularly lengtluwise and in the midclle of the hinder half a middle row of indistinct herringbone markings. In alcohol the markings are more distinct and there is none of the red color which is so evident in the other species of Dendryphantes. PI. VI, fig. 5. The legs are pale with faint brown marks across the middle of the joints which are deeper colored on the patella, tibia and femur of the first legs. On the under side the legs arc palc, including the coxa and sternum, with no marking except on the front pair. The under side of the abdomen has three black stripes from the epigynum, nearly to the sjinnerets and at the sicles the waving black lines extend underneatlı. Fig. $5 \mathrm{a}$. The epigynum has a short rounded notch showing nothing distinctive.

Gloucestcr, Mass. in a sphagnum bog, Aug. 25, 1910. Found before by Banks in the southern states from Waslington to North Carolina.

\section{Sittacus striatus, new.}

Femalc $5 \mathrm{~mm}$. long. Male $3.5 \mathrm{~mm}$. Cephalothorax in both sexcs $2 \mathrm{~mm}$. long. The cephalothorax is less narrowed in front and has the sides straighter than in S. palustris. The cephalothorax has three narrow light stripes. The markings of the abelomen are much like those of the female Dendryphantes militaris, the middle markings only slightly larger than the others. Pl. VI, figs. 6, 61). Neither specimen has the large middle light mark which is conspicuous in palustris. 'The legs are striped lengthwise, while in palustris they are ringed crosswise, but on the under side there are indistinct rings on the femura. The general color is light yellow-lorown like straw, much lighter than the usual color of palustris. The male palpus has a sharp process on the outside of the tibia nearly as long as the rest of the joint, as in palustris, but the bulb of the palpal organ is circular while in palustris it always has a depression on the onter elge. Figs. 6, 6e.

A male and female were taken in straw on a salt marsh at Plum Island, Nass., June 17 and another female in a sphaguum bog at Bangor, Me. June 30. 




\section{PLATE I}

1 Theridion globosum, side of $\delta$. I a cephalothorax, eyes and palpi from above. $1 \mathrm{~b}$ sternum and palpi from below.

2 Teutana grossa, dorsal markings of 8 . 2a sternum and maxillæ.

3 Pedanostethus fuscus, base of palpal organ, 3 a same of P. pumilus, $3 \mathrm{~b}$ same of $P$. riparius, $3 c$ same of $P$. spiniferus.

$\$$ Ceratinella sphaerica, side of $\delta$. 4 a dorsal view of $\delta .4 \mathrm{~b}$ male palpus. te tibia and tarsal hook of male palpus.

5 Ceratinella carinata, tibia and tarsus of male palpus. 5 a same of C. laetabilis. 5l same of C. laeta. $5 \mathrm{c}$ same of C. brunneus.

(; Grammonota trivittata, cephalothorax and palpi of $\delta$. 6 at same of $G$. ornata. $6 \mathrm{~b}$ male palpus of $\mathrm{G}$. trivittata. $6 \mathrm{c}$ same of G. ornata.

7 Araeoncus bispinosus, side of cephalothorax of $8.7 \mathrm{a}$ head and palpi of $3.7 \mathrm{~b}$ male palpus. $7 \mathrm{c}$ sternum.

8 Dicymlium pectinatum, side of cephalothorax of ${ }^{3}$. 8 a metatarsus of first leg. $8 \mathrm{~b}$ upper side of male palpus. $8 \mathrm{c}$ outer side of right palpus. $8 \mathrm{~d}$ under side of male palpi.

9 Histagonia nasuta, cephalothorax of $\delta$. 9 a side of cephalothorax of $\delta$. $9 \mathrm{~b}, 9 \mathrm{c}$ male palpi. 
Plate I
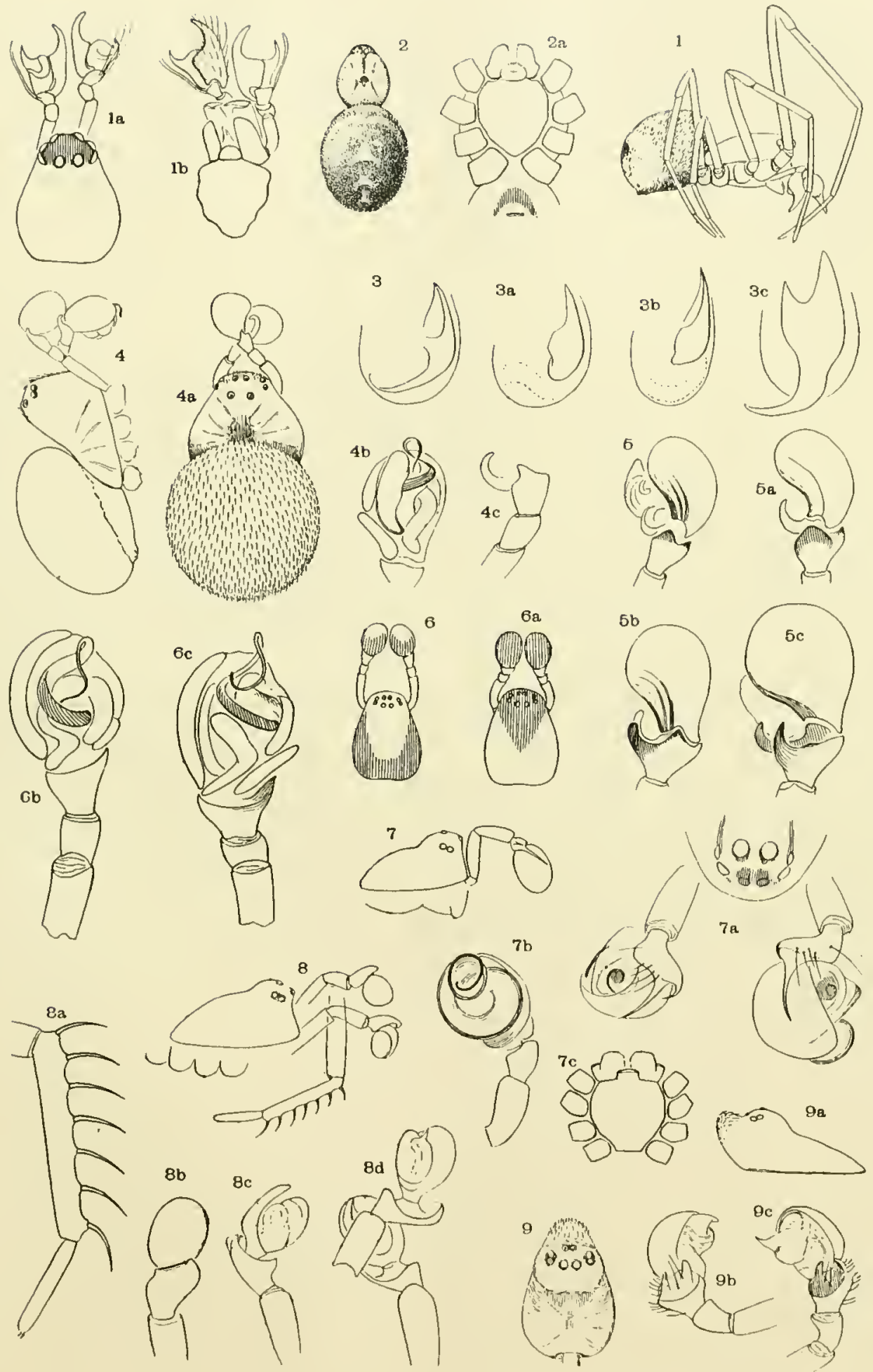




\section{PLATE II}

1 Lophocarenum bilobatum, male from above. $t$ a side of cephalothorax. $t b$ male palpus.

2 Lophocarenum exigum, side of cephalothorax of male. 2a front of male and palpus. 26 lelt palpus. $2 \mathrm{c}$ top of head.

3 Lophocarenum excavalum, side of male. 3a head of male from in front and above. 31 ) male palpus. $3 \mathrm{c}$ eprigynum.

4 Lophocarenum arenarium, dorsal view of male. 4a sicle of cephalothorax. 4b male palpus, outer side. $4 \mathrm{c}$ epigynum.

5 Lophocarenum domiciliorum, head and palpi of male. 5a side of head. 5l male palpus. $5 \mathrm{c}$ tilsia of male palpus, inner side.

6 L.ophocarenum flagellatum, head and palpi of male. 6 a cephalothorax slightly turned to show grooves in head. 61) side of ceplialothorax.

7 [ophocarenum decemoculatum and florens. 7 eyes of decemoculatum. $7 \mathrm{a}$ eyes of florens. $7 \mathrm{~b}$ ejigynum of decemoculatum $7 \mathrm{c}$ epigynum of florens.

8 L ophocarenum (Tmeticus) armatum. 8 dorsal view of cephalothorax showing pits in the head, eyes and mandibles. 8 a side of cephalothorax. 8l) under side of cephalothorax. $8 \mathrm{c}$ head and eyes of female. $8 \mathrm{~d}$ under side of female. $8 \mathrm{e}$ male palpus. $8 \mathrm{f}^{\circ}$ patella of male paljus from the side. $8 \mathrm{~g}$ front of head and mandibles of male. $8 \mathrm{~h}$ tarsal hook and base of tarsus. 
Plate II

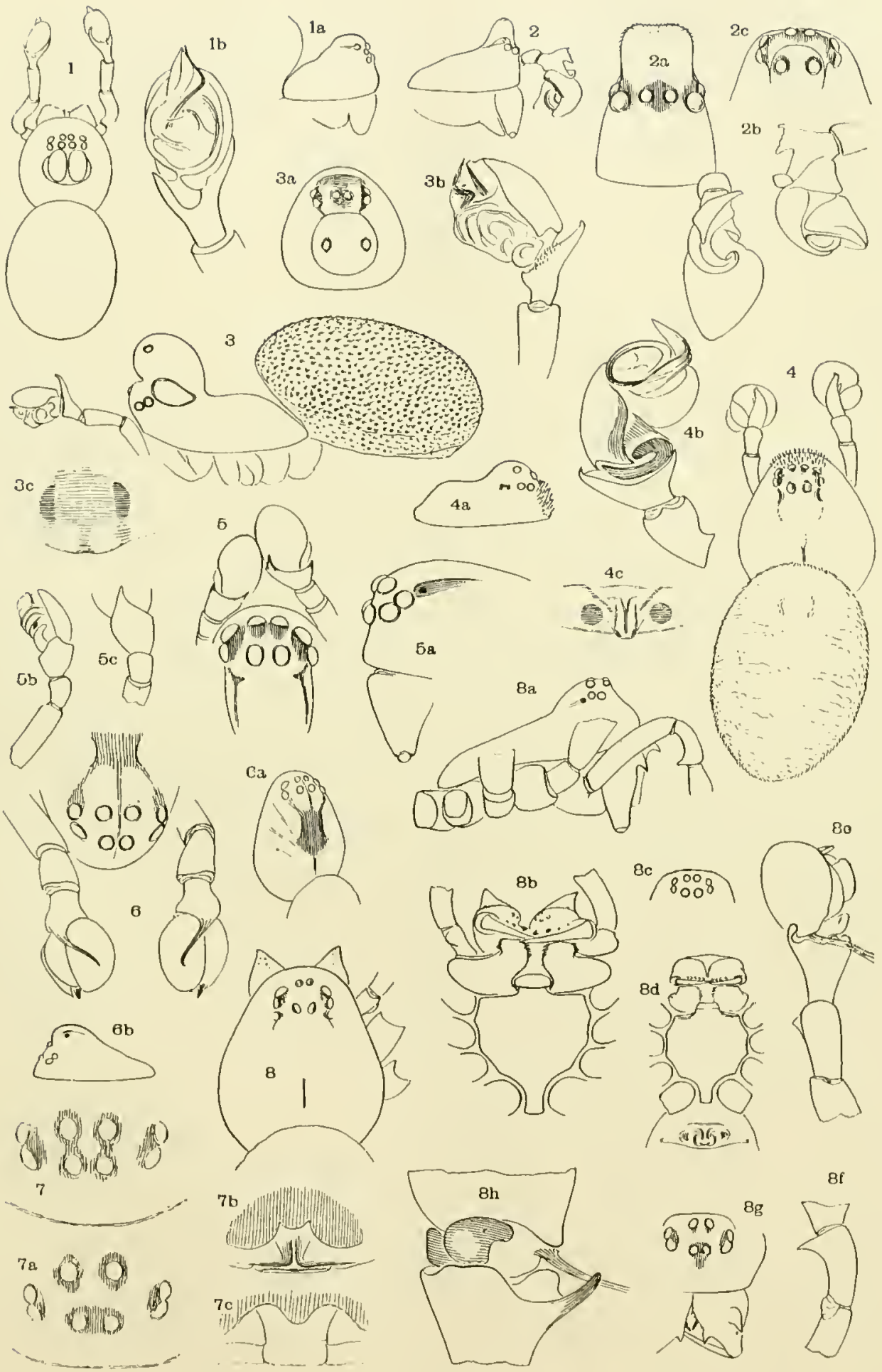






\section{PLATE III}

1 Tneticus aestivalis, male palpi from below. 1 a palpus from outer side. 1l) palpus from above. $1 \mathrm{c}$ epigymum.

2 Tmeticus tarsalis, side of cephalothorax of 8 . 2a palpal organ. 2l) male palpus showing tarsal hook and wide tarsus.

3 Tmeticus entomologicus, head and palpi of 3 . 3 a male palpus from side.

4 Tmeticus tenuipalpis, side of $\delta$. 4 a maxillre and mandibles of $\delta$. $4 \mathrm{~b}$ front of head and mandibles of $\delta .4 \mathrm{c}$ male palpus from below. 40 male palpus from above. 4e epigynum.

5 Microneta olivacea, cephalothorax and palpus of $\delta$. 5 a male palpus, outer side. 5b side of cephalothorax of male. $5 \mathrm{c}$ side of cephalothorax of female. $5 \mathrm{~d}$ palpus of female. $5 \mathrm{e}$ palpus of female from Narcross, Me., without enlarged tarsus. $5 \mathrm{f}$ mandible of female. $5 \mathrm{~g}$ top of cephalothorax of female. $5 \mathrm{~h}$ front of temale showing enlarged palpi. $5 \mathrm{j}$ and $5 \mathrm{k}$ epigynum.

6 Bathyphantes theridiformis, loack of male. 6a male palpus. 6b mandibles of male. 6c epigynum.

7 Bathyphantes intricata. 7, 7a, 7l, $7 \mathrm{c}, 7 \mathrm{~d}$ male palpus. 
(5)
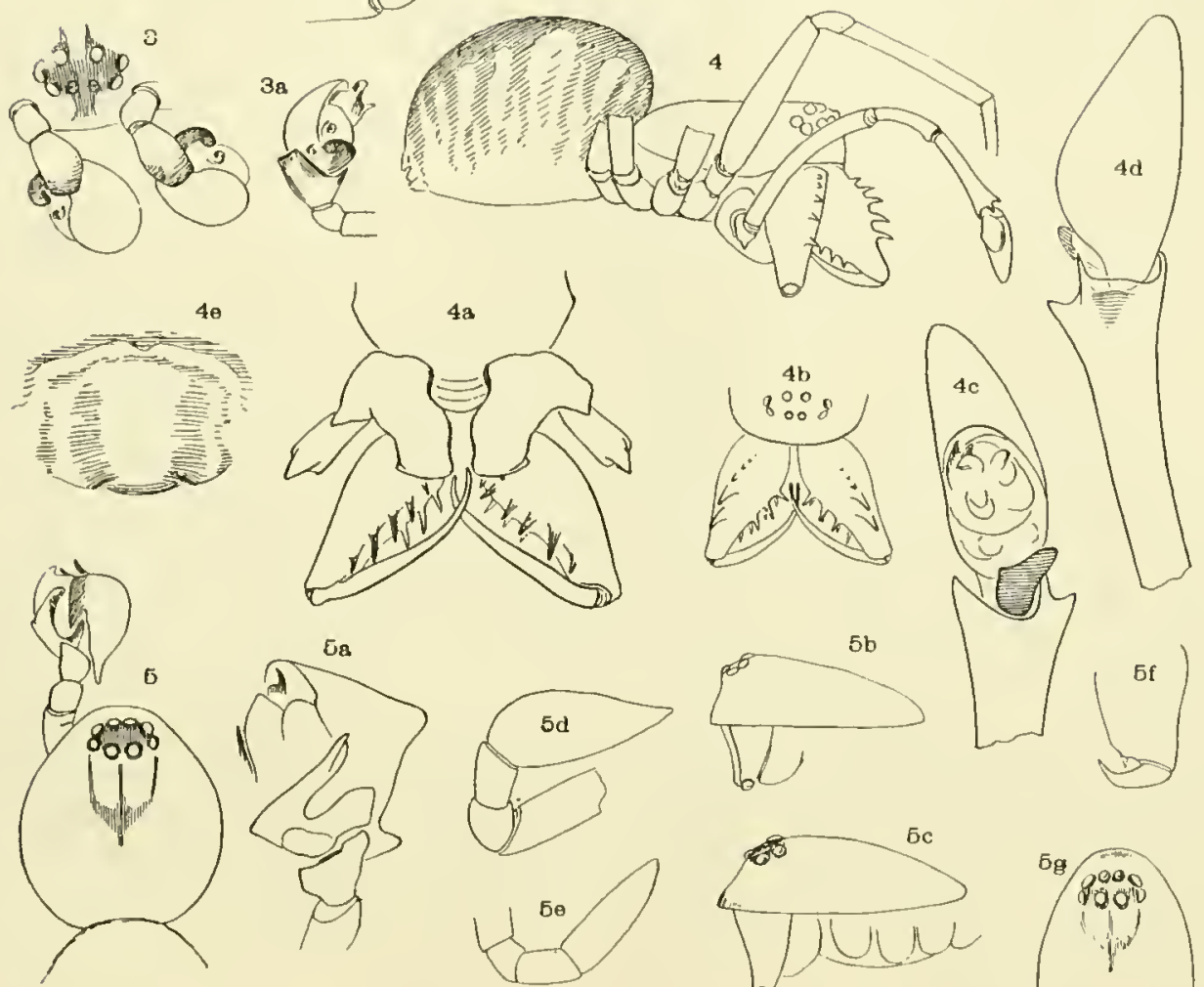

बखल
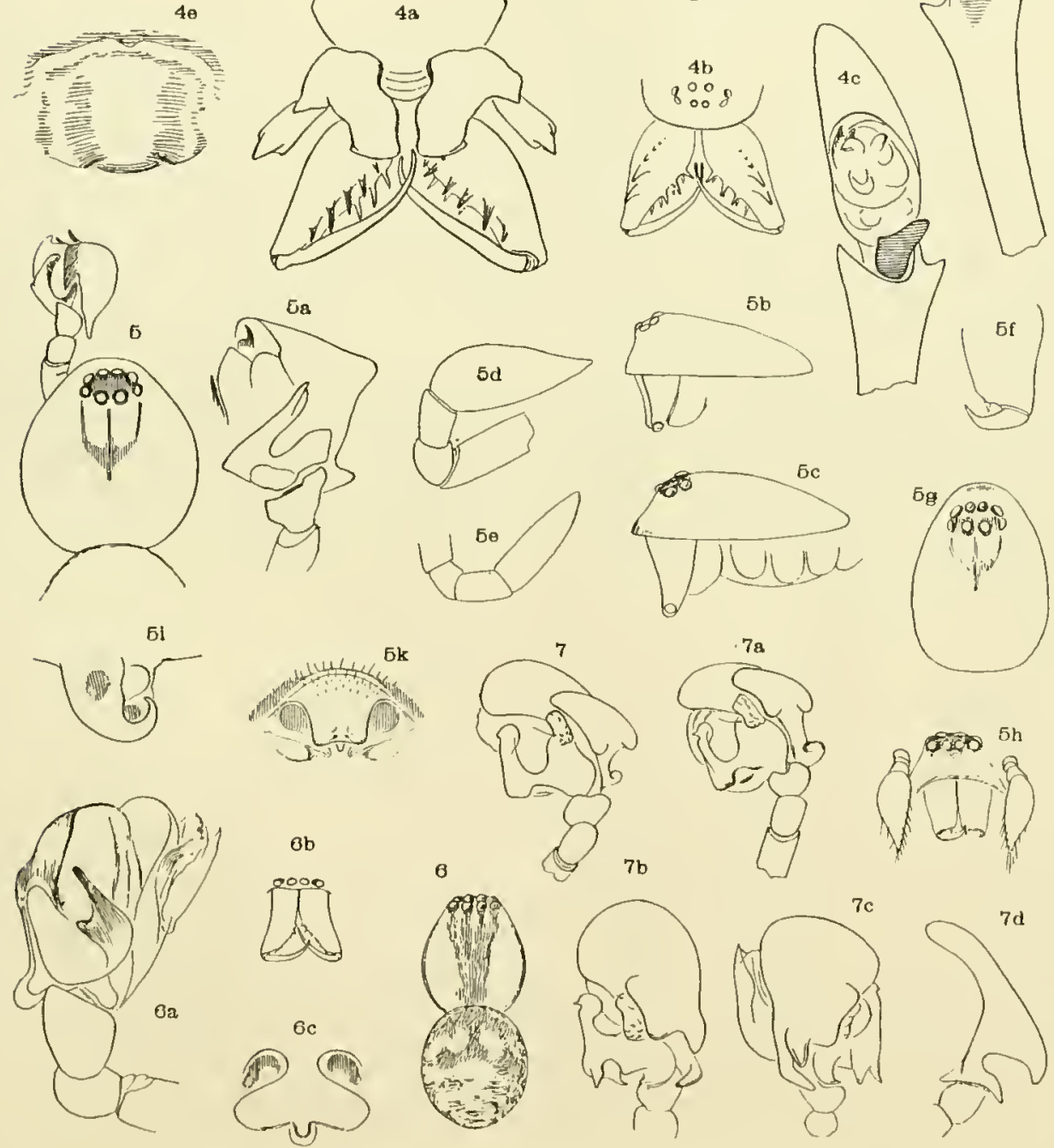




\section{PLATE IV}

1 Diplostyla brevis, outer side of male palpus. 1 a monder side of male palpus. $1 \mathrm{~b}$ epigynum.

2 linyphia humilis, front and mandibles of male. 2 a top of head and palpi of male. 2b dorsal markings of female. $2 \mathrm{c}$ side of abdomen. 2ud epigynum.

3 Dictyna terrestris, side of head and palpus of male. 3 a mandibles of 8 . $3 \mathrm{~b}$ male palpus. $3 \mathrm{c}$ head and palpus of male. $3 \mathrm{~d}$ head and palpus of 1 . volupis for comparisus.

4 Aryenna obesa, under side of female. 4 a back of female. $4 \mathrm{~b}$, $4 \mathrm{c}, 4 \mathrm{~d}, 4 \mathrm{e}$ male palpus.

5 Lathys foxii, dorsal markings. 5 a under side of female. $5 \mathrm{~b}, 5 \mathrm{c}$ male palpus. 50 male palpus from above. 5e eyes.

6 Pisaura brevipes, clorsal markings and diagram showing relative length of first leg. 6at epigynum. 6b diagram showing relative length of first leg of P. undata. bic epigyum of P. undata. 
Plate IV
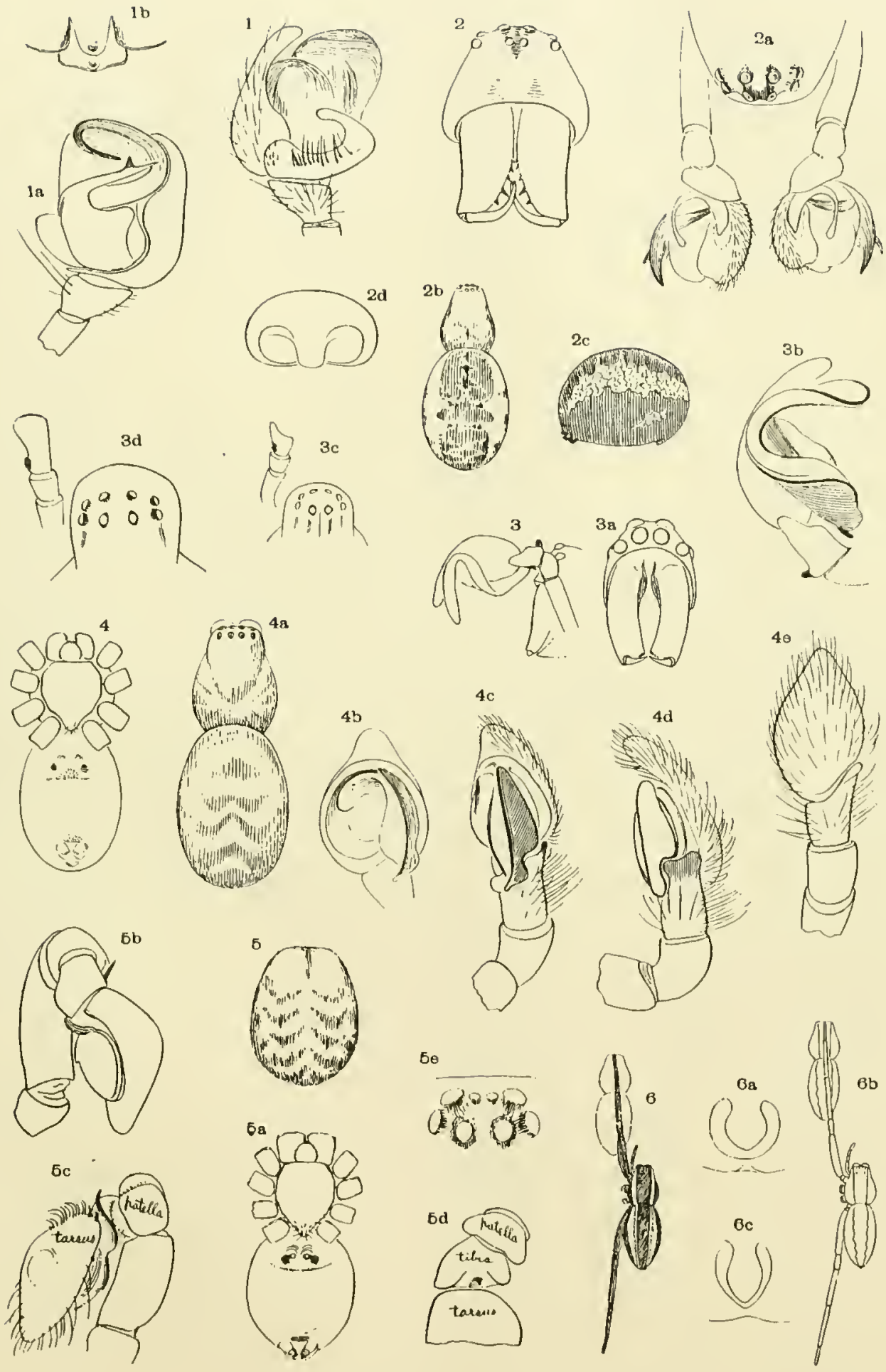




\section{PLATE $V$}

1 I.ycosa 4uinaria, back of $\delta$ with palpus. 1 a palpus of $\delta$ usder side.

2 Partosa muscicola, dorsal markings of $\delta$. 2 a male palpus from below. 23) male palpus from the side. 2c epigyums.

3 Pirata montana, dorsal markings. 3 a palpus of $\delta$, under side.

4 Liocranum calcaratum, back of $q$. 4 a under side of $q$. $4 \mathrm{~b}$ first leg of $q$ showing spines. $4 \mathrm{c}$ back of $\delta .4 \mathrm{~d}$ epigynum. $4 \mathrm{e}$ male palpus. If male palpus showing palpal organ.

5 Zora spinimana, dorsal markings of $q$. 5 a epigynum. $5 \mathrm{~b}$ first leg showing spines.

6 Micaria longispina, palpal organ. $6 \mathrm{a}, 6 \mathrm{~b}$, palpus of $\delta$ showing tilial spine.

7 Prosthesima rufula, palpus of $\delta$.

8 Prosthesima depressa. 8, 8a, $8 \mathrm{~b}$ three forms of tibjal spine. $8 \mathrm{c}$ palpus of 8 showing palpal orgau.

9 Prosthesima transversa, palpus of 8 showing palpal organ. 9 a tibial spine from above. 9l tibial spise from outer side. 
Plate V
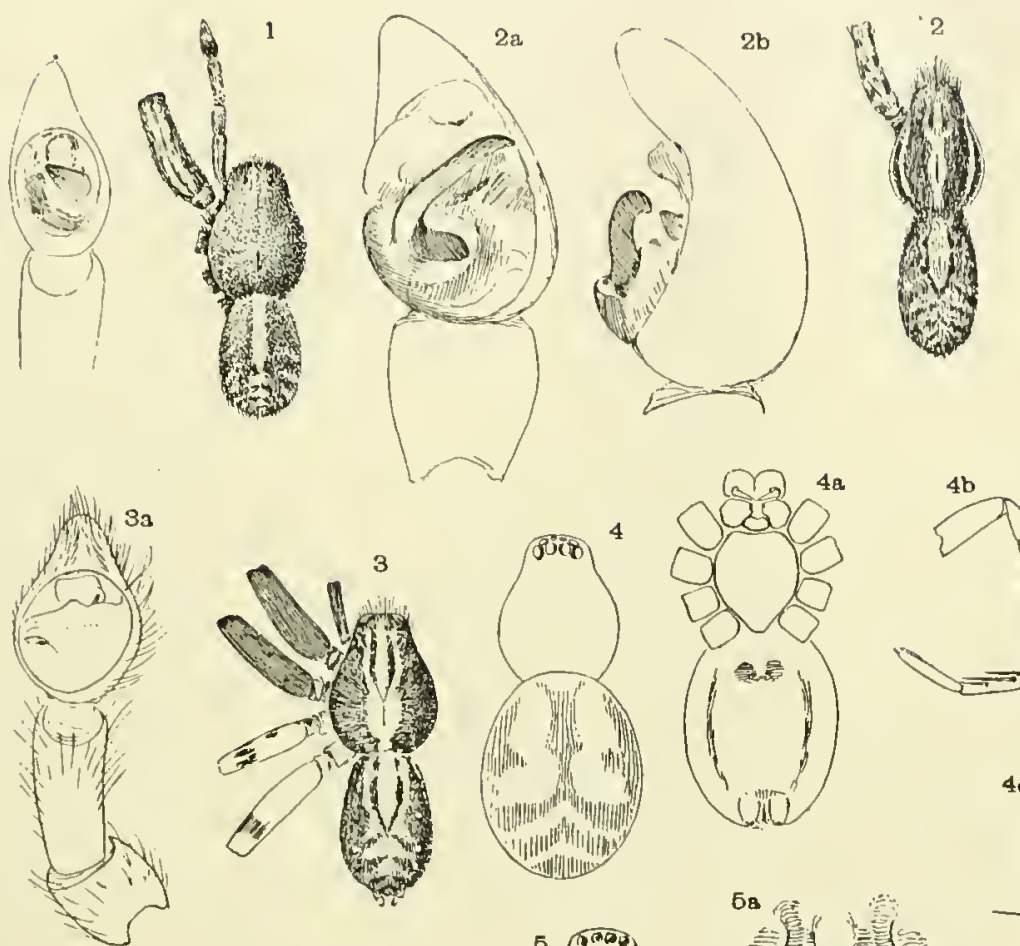

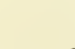

830
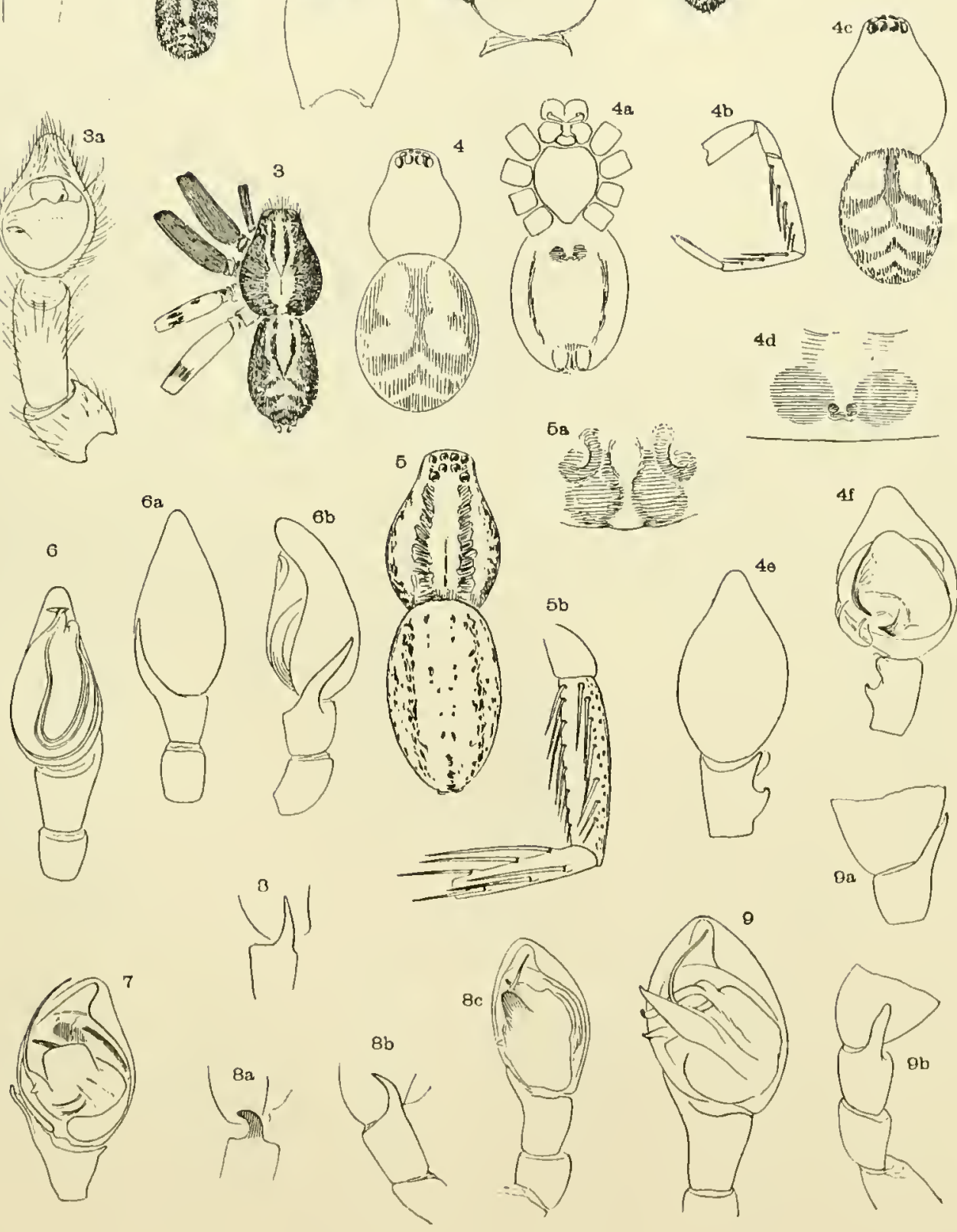




\section{PLATL VI}

1 Phrurolithus formica, back of female. 1 a stermun and maxillae. $1 \mathrm{~b}$ epigynum of old female. $1 \mathrm{c}$ epigynum of young female. $1 \mathrm{~d}$ palpus of male. 1 e palpus of 8 from above.

2 Phrurolithus mimutus, back of $\delta$. 2 a palpus of $\delta$. $2 \mathrm{~b}$ tarsus of palpus from aloove.

3 Phrurolithus borealis, palpus of $\delta$, outer side. 3 a tarsus of palpus.

4 Phrmrolithus alarius, palpus of $\delta$, outer side. 4 a palpus of $\delta$ from ahove.

5 Dendryphantes castaneus, dorsal markings as they appear in alcohol. 5a markings of under side.

6 Sittacus striatus, palpus of of showing palpal organ. 6a female from above. $6 \mathrm{l}$ ) dorsal markings of $q .6 \mathrm{c}$ ventral markings of $7.6 \mathrm{~d}$ dorsal markings of $\mathrm{S}$. palustris. 6e male palpus of S. palustris. 


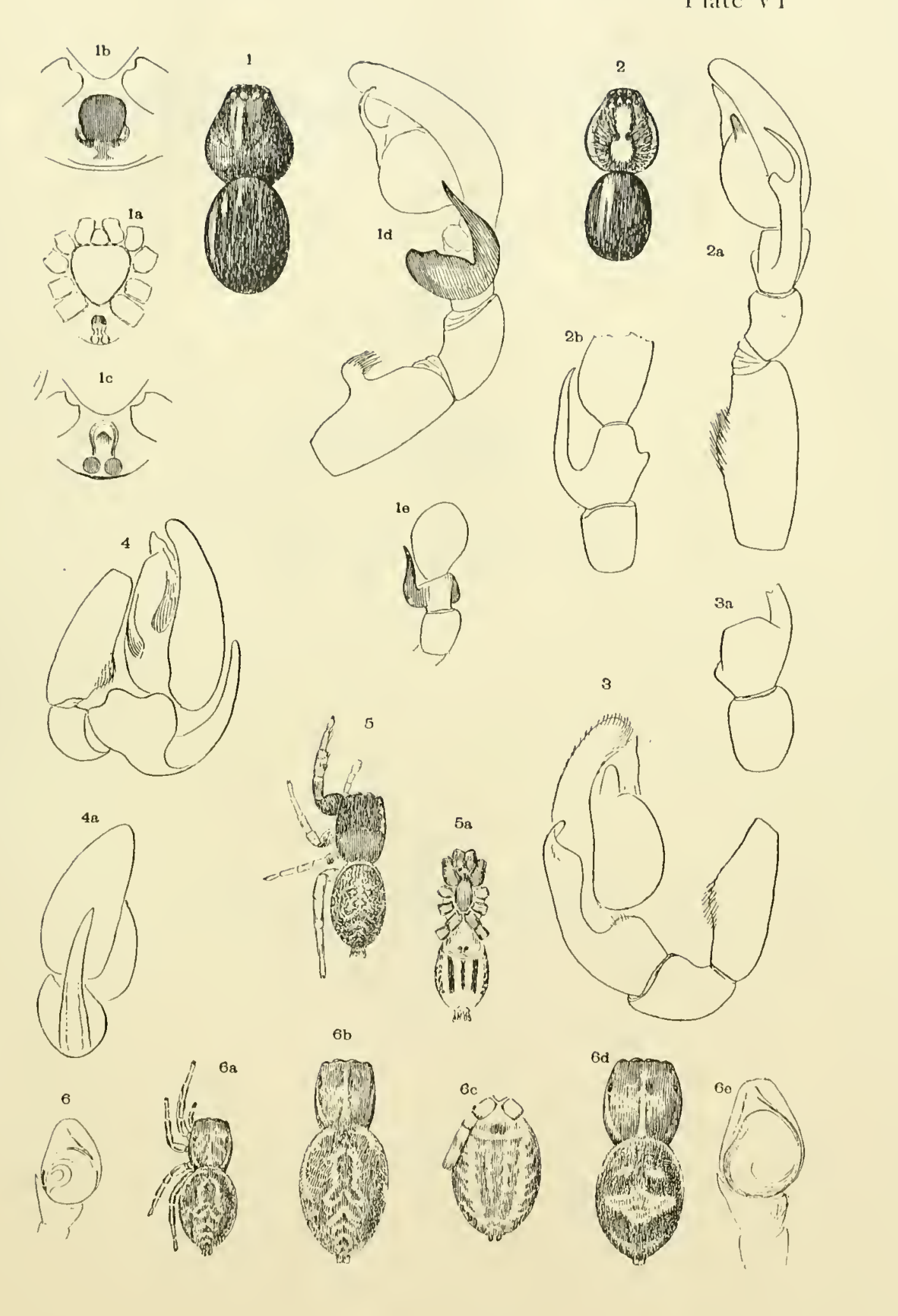





\section{CONNECTICUT AGADEMY OF ARTS AND SCIENCES \\ Inconfor 1 TFe $\wedge$. D. 1799}

\section{Publications}

\section{of Yale University}

\section{YALE UNIVERSITY PRESS}

NEW HAVEN, CONNECTICUT

1011 

OFWICERS FOR 1910-11.

I'residernt.

HON. SIMLON R. BAILDIVIN.

Vire-pursillewls.

Prof. Alexander W. EVANS,

Prof. CLIVE DAY, PROF. HANNS OEJTEEL.

Sicretary.

Dr. GEORGE F. EATON.

Treusurer.

Mr. GEORGE PARNLY DAY.

Libvarian.

Mr. JOHN CHRISTOPHER SCHWAB.

Commatere on Publeation.

IJon. S. F. BAIJWIN, Chniman,

Prof. A. S. COOK,

Prof. E. S. DANA,

Prof. J. P. MORRIS,
Pnof. A. W. EVANS,

Prof. Clilve DAY,

Prof. H. OEI'T'EL,

Mr. .I. C. SCIIVA 3 . 



\section{CONTLNLS.}

Page

Anditions to the library, May 1, 1910 to June 30, 1911 .

VII-xxIx

Art. I. - The Amphiloda of Bermona. By Beterly Wavgh Kunkel 1-116

Art. II.-The Chausula in Ammanus Marceldinus. By Austin

Morris himmon . . . . . . . . . . . . . 117-245

Art. III. - Nutrition Inyestigations on the Carbohymates gf

Lichens, Aloae, and Related Substances. By Mare

Davifs Swartz . . . . . . . . . . 247-382

Art. IV.-New Spiders from new Enoland. By J. 1I. Emerton 383-407 



\section{ADIMITIONS 'TO 'THE LIIBRARY}

OI TIE

\section{CONNECTICUT ACADEMY OF ARTS AND SCIENCES}

By Gift and Exchanee from May 1, 1910, to June 30, 1911.

Aix-en-Provence. - Université.

Faculted des lettres Anuales I-III, 2. 1907-09.

Faculté de droit. Amnales I-IV, 2. 1907-10.

Faculte de droit et rles lettres. Annales I-II, 2. 1905-06.

Altenisuri, S.-A. Naturforschcnle Gesellschufl des Ostcrlandes.

Mitteilungeu aus dem Osterlande. N. F. 1910.

Anerican Academy of Arts and Sciences.

Proceedings. XLVI, 13-24, XLV11, 1-3. 1911.

Ancrican Antiquarian Society.

Proceerlings. XX, 2. 1910.

American Geographical Socirty.

Bulletin. XXXIX, I-XLIII, 6. 1907-11.

American Museum of Natural History (New York).

American Museum Joumal. X, 3-X1, 5. 1910-11.

Guide Leaflet. 24, 26-30, 33. 1907-11.

American I'hilosophical Society.

Proceedings. X1,V111, 194-I, 198. 1909-11.

American Society of Sanitary and Moral I'rophylaxis.

Elucational pamphlets. 1-6. 1910.

Anherst Colneoe.

Catalogue. $1910-11$.

Amiens.-Académie des Sciences.

Memoires. INI. 1909.

Société Limnécnuc du Nord de la France.

Bulletin. No. 225, $1891 ; \mathrm{XIX}, 381-92.1908-09$.

Amstenda.,-Koninkl. Akudemie van Wetenschappon.

Jaarboek, 1909.

Proceedings. Section of sciences. X1I, 1-2. 1909/10.

Verhandelingen. Afd. Natuurkmde, Sectie II, Deel XV, 1-3, XVI, 1-S. 1909/10.

Verslagen van de gewone vergaderingen van de wis- en natuurkundige afdeeling. Deel XV111, 1-2. 1900/10.

Mautschappij tot nut wan 't Algemeen.

Publikation. 93, also IX, 4. 1911.

The Apteryx. (Roger Williams Park II useum, Providence, 1R. 1.), 1, 1-3. 1910. Argentine Republic.

Agricullural and pastoral census of the nation. Monograph. IIII. 1908. 
Austrulasian Association for Advancement of Science.

Report of Mleeting. XII. 1909.

Address of President. 1907. Section C.

Banberg.-Lemeis Stemuarte.

Veröffentlichumgen. Reihe II, Band I, lleft 1. 1911.

BASEL. Nalurforscheule Gesellshaft.

Bericht. XII. 1909.

Verhandlungen. XX, 3-XXI. 1910.

Batavia, - K. Nuturrandige Voreeniging.

Natturkundig' Tijdschrift. Xl, Ser. 8, I; XLIII, 1-4.

Ii. Magnetical and Meteorological Observatory.

Observations. XXX-XXX1 and append. 1907-08.

Observatory.

Erdbeben Berielit. 6a-c, 7a-b, 8a, 9a, 11a, 12a. 1909.

Seismologicat Bnlletin. dan. to Dec. 1910; Feb. 1911.

BELanus.-Acalémie Ii. d'Archéologie de Belgique.

Bulletin. 1-1V. 1510.

BERGEN.-MUSeUm.

Aursberetuing. 19001.

Aithog. 1909, 2 to $1910,2$.

Crustacea of Norway. By G.U.Sars. Vol.V, parts XXVII-XXX.

BerLan.-K. Mustum für Noturkinale.

Mitteilnugen ans item Zowhogischen Museun. IV, 3; V, I-2. $1910-11$.

Bericht des Zoologischen Museums. 1909.

Bimminghano- Natural Hislory and Philosophical Sucicly.

List of Members and Anmal Report. 1910-11.

Proceedings. I-XII.

Bologna.- li. Accudemia delle Scienze dell'Istituto di Bologna.

Memorie. Classe di S'cienze Morati. Sezione di Scienze Storieofitolugiche. Ser. I. T. III, 2-1Y, 1. 1908-10. Sezione di Science Giuridiche. Ser. I. 'T'. III, 2-IV, 1. 1908_10. Adunanza, June 22. 1910.

Rendiconti. Classe di Scienze M[orali. Ser. I. T. Ill. 1909_10. Classe di Scienze Fisiche. Anno 188:-4; N. S., V, 1-4. 1900-01; Xlll, 1908-0!.

Bомиау. - R. Asiatic Society.

Journal, Bombay Branch. IXIV. 1909.

Bann.-Nuturlistorischer Verein der preussischen Tiheinlande und Westfalens. Sitzmingsterichte. 1909,2 to $1910,1$.

Verluaulungen. I-IV, VI-VII, XXIII, 1-2, 1844-66; LAIT, 2. 1110.

Bordeavx. Commission Météorologique de la cirronule.

Bulletins. 1908, 1905\%.

Sociêté des Ściences Physiques et Nuturelles. 
Mémoires. T'. V, 1.

Procès-verbaux. 1908-09; 1909-10.

Buston, Mass.-Museum of Finc Arts.

Bulletins. $46-51$.

Annual lieport. XXXV, 1910.

Society of Naiural History.

Proceedings. XXXIV, 9-12. 1910.

Brabford.-Scientific Association.

Jourual. 111, 2. 1910.

Bremen. - Meteorologisches Obscrvatorium.

Deutsehes Meteorologisches Jahrbuch. XX. 1909.

BrF.sud.-Schlesische Geselischaft für vaterländische Cullur.

Jahres-Bericht. LXXXVIII, 1909.

Naturvissenschaftlicher Verein.

Ablancilungen. $\mathrm{XX}, 1.1910$.

Brooklyn.-Museum of the Brooklyn Institute of Arts and Sciences.

Bulletins. IV, 11, 14-16; VI, 3-8, 15. 1910-11.

Scjence Bulletins. I, 17 and Index, 1910.

Museum News. V, 6-8; VI, 1-8. 1911.

Year Books. 1907/08-1909/10.

BRÜns.-Nuturforschender Vercin.

Verhandlungen. XLVII. 1909.

Brunswick. - Verein für Nalumvissenschaft.

Jaliresbericht. XVI. 1907/08-1908/09.

Brussets.-Acalémie $R$. des Sciences, des Lettres et des Beaux-Arts de

Belgique.

Annuaire. LXXV1-LXXVI], 1910-11.

Bulletins. Classe des Sciences. 1909, 9 to 1911, 4.

Mémoires. Classe des Sciences. Sér. 11. T. II. Fase. VII-

VIII. T. III. Fase. I-1V in 8vo. T. II.

Jardin Botanique de l'fitat.

Bulletin III, I.

Musée 1R. d'INistoire Naturelle.

- Mémoires. 'T. IV-V. 1907-08.

Observatoire Royale.

Annales $\Lambda$ stronomiques XII, 2-XIII, 1. 1910.

Aunuaires $\Lambda$ stronomixpes. 1911-12.

Société Intomologique.

Annales. LI11-1,1V.

Mémoires. XVIII. 1911.

Socićte $R$. de Botanique.

Buhletins. XLVI, 1-4, XLVII, 1-4; also XVI-XVII, 1-3, XVIII, XX. 1878-1881.

Société R. Belye de Géographie.

Bulletin. XXX111, 1-XXXIV, i. 1909-10. 
Brussels. - Socićté 7 . Zoologique et Malıcologique.

Annales. XLIV. 1909.

Sociétć des Sciences.

Annales. XXXIT, 2-4; $\mathrm{XXXY}_{1}, 1-2.1909 / 11$.

Revue des Questions Scientifiques. Sér. III, XVIl, I-XIX, 2. $1910-11$

Bucarest.-Observaloral Astronomic si Meteorologic.

Bulletin Tanar. AVl. '1907.

Sociëté dés Sciences.

Bulletins. XVI, 1-2; XV111, 5-XXI, 1; nlso II, 7-19, 1I1, $1-2, x, 5$.

Buchan Fiell Club Mherem, Peterhead.

'T'ausactions. N. S. 1, 1.

Bubarkst.-Acalémie Hongroise des Sciences.

Mathematische und Naturwisseuschaftliche Bericlite aus Ungarn.

XXIV-XXV. $1906-07$.

Rapport sur les 'Travanx. l:009.

Kiralyi Magyar Tudomán, ligyeten Tanrede. $1903 / 0.1 ; 1905,06-1908 / 09 ; 1910 / 11$.

Buenos Anes. - Virección General de Estadistica.

Boletin Mensual. X, 108-XI, 120. 1909-10.

Museo Nacional.

Anales. Sier. 111. 'I'. II-XIII. 1910.

Suciedal Cientifica Argentina.

Anales. LX1X, 1-LXX, 4. 1910.

Burfalo.-Society of Nutural Sciences.

Bulletins. X, 1. 1910.

Cann.-Société Linuéenne de Normandie.

Bulletin. Sér. 6;, 'T. 11. 1908-0"\%

Mémoiles. XXIll, 1-2. 1908-05.

Calcutta. - Asialic Society of Bengal.

Journal and Procedings. IV (1ndex); V, 1-11; V1, 1-6. $1408-10$.

Memoirs. TII, 1.

Historicul Society.

Anumal Report. 1910.

Jourual. Y (No. 10). 1910.

('alifornia Academy of siciences.

Proceedings. I, lpp. 7-48s (1 th Ser.); 111, Pl). 57-72 (4 th Ser.).

Camiras.-Société d'Emulation.

Mémoires. TAIII-LXIV. 1908-09.

Cambridae (Gingland).-Observatury;

Report. 190:-10.

Ihitosophicat society.

'Iransuctions. XX1, 10-14; ludex to X111. 
Cameron, Lan-Gulf Binlogic Station.

Bulletin. Y. 1910.

Canama-Geologicnt Survey.

Department of Mines. Summary Repurt. 190s.

Maps 1006, 1008, 1077, 108:, 1091, 1093, 1101, 1110, 1115, 1137.

$11.13,11 \% 0$.

Department of the Interior.

Maps, Manitoba, Saskatehewan and Alberta. 1909.

Forestry Branch. Bulletin. !) 16-20.

Canadian Rallway Club.

Official Proceedings. X, 1-5. 1911.

Caradoc and Severn lalley Ficld Club, Shrewsiur.

Record of Bare Facts. 20, 1910.

'Transactious. V, 2.

Catani.-Accudemia Gioenia di Scienze Naturali.

Bolletino delle Sedute. Ser. I1, 11-17. 1910-11.

Socicte degli Spettroscopisti Italiana.

Hemorie. XXXLX, 1-7, 9-11; XL, 1-3. 1910-11.

Cellule, La. XXVI, 1. 1910.

Chapultepec. -Observatorio Astronomico National.

Anuario. XXX1. 1911.

Chemnitz. - Naturwissenschaftliche Gesellschaft.

Bericht. XVII. 1909.

C'herbourg.-Saciétè Nationale Académique.

Mimoires. XVIII.

Chicago.- Fïld Mtuscum of Netural llistory.

l'ublications. 142-150.

Christianis. - Nyt Magazin for Naturvilcnskaberne. XLLX, 1. 1911.

Videnskabs-Selskabet.

Forhandlinger. 1909.

Cнur. - Naturforschende Gesellschaft Granbiindens.

Jahres-Bericht. III. 1909-10.

Cincinnati. - Lloyd Library.

Bulletins. Mycological Series, 3 (1902), no. 1; 13 (1900), no. 4.

Płarmacy Series, 12 (1910), no. 2.

Report of Lloyd Mycological Mnseum. 1. 1895.

Bibliographical Contributions. 1-2. 1911.

Mycological Notes. 32-5. 1909-10. Jndex to II. 1905-188.

Muserm Associntion.

Annual Report. XX1X. 1909.

Journal. XX 1, 2. 1910.

University.

Report of C'luairman and President. 1909.

Observatory Publications. 17. 1905-10.

Record. V], 5-VII, 4. 1910-11

Universily Stndies. Ser. 11. Vol. VI, 1-4. 1910. 
Colorado college.

I'ullicutions. (ieneral Series. 50-52, 55. Suiene Series. X11, 25, 47-45. Social science Series. 1I, 8.

Coloralo Scientific Sucicty.

Proceedings. IX, 315-X, 38.

Jear-Books. 188_-1910.

C'ulokado.-University of:

Studies. VII, 2-VIII, 3. 1910-11.

connecticut Historical Society

Amual Report. 1910.

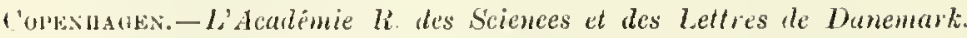

Bulletin (Oversigt). 1909, $1 ;-1911,1$.

Naturhistoriske finening.

Videnslsulvelige Meddelelsel. 1509.

r'uñ̃a.-li. Academia Galleya.

Binletill. V, B3-VI, 165 .

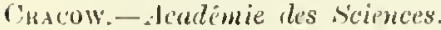

Materyaly. 19117-0).

K. K. Stermirte

liesultate. 1910.

Metenrologisehe Beoharditungen. Marh 1910-May 1911.

Cunzon.-Microstopical clul.

lieports and Abstrints of P'inceelings. I-V, VI-VIII, 18711878.

Anmul Procedings and Transactions. 1878/81 to 1909/10; 1ndex to $1570 / 83$.

Nitural History and Scientific Society.

Annual Proceedings and Transations. 1909-10.

Danzui.-Naturiorschende Gesellschaft.

Katalog der Bibliolhek. Heft 2.

Schriften. N. IV. I3d. XII, 4.

Westpreussischer Dotaniseh-Zoologischer V'erein.

Berichte XXVI-XX1X; XXXI-XXXI1. 1905-10.

Divenport, In.-Academy of Sciences.

Proveedings. XII, pr. 203-40

Dexisun Unirersity.

Bulletin of the scientinc Laboratories. XVI, 1). 1-316. 1910.

DETrolT. - Wuseum of Ast.

Annual lieport. 1910

Bulletins. IV, 2-V, ‥ 1910-11.

Dhos.-Académie des Sciences, Arts et Belles-Lettres.

Mémoires. 3e súr. T. 11-111. 1874-7i. te Sér. T. Il 1907-10.

10onis.-Gelehte Estniside Gesellschaft.

sitzmugrslieridule. 19069. 
Dorpat.-Natierforscher-Gesellschoft.

Arehiv. Ser. II, Band VI.

Sitzungsherichlie. XVIH, y-1. 1909.

Dresden,-Natumissenschufliche Gesetlschaft Isis.

Sitzungsberichto und Abhandlungen. July, 1909 to Dee., 1910.

DobLin.-Royal Dublin Socicty.

Economic Proceedings. II, 1-2.

Scientific Proceedings. N. S. VII, 2I-36; Index. 1898-190!.

Scientilic Transactions. V, $2 d$ ficries, VI.

R. Irish Acalcmy.

Procedings. Series $\Lambda$, XXVull, $1-\mathrm{XXIX}, 2$; Series $B$, Xxvil, I-Xxlx, I; Series C, XXVII, 10, XXVIll, IXXIX, 4.

Clare Island Survey. XXXI, 4-5, 22, 39.

Trinity College.

Hermathena. 31-36. 1908-10.

Detch East Inmes.-K. Naturkundige Verceniging.

Natumrkundige 'Tijdschrift. LXIX.

East Kent Scientific and Natural History Socicty.

Transactions and Reports. Ser. II. Vol. IX.

Eninuuron.-Botanical Society.

Transactions and Proceedings. XXV.

Geological Society.

Transactions. IX, special part and $\mathrm{V}$.

R. Observatory.

Aunals. III. I908.

R. Physical Society.

Proceedings. XVIII, 2.

Royal Sociely.

Proceedings. XXX, 5, 7; XXX1, 1-3.

Elberfeld.-Chomisches Untersuchungsamt.

Bericht iiber lie Tätigkeit. 1908.

Naturwissenschaflicher Verein.

Jahres-Bericht. XII. 1909.

Elisha Mitchell Scientific Society.

Journal. XXV, 3-XXVI, 4.

Emen.-Naturforschendc Gescllschaft.

Jahresbericht. XCIV. 1908/09.

Kleine Sehriften. 4, 6-10, 14.

Erfurt. K. Alcademie geneinutitziger Wisschschaften.

Jahrbiiclier. XXXV. 1909.

Essex Instilute.

Annual Report. 1910, 1911.

Frorence.-Biblioteca Nazionale Centrale.

Bolletino. 110-124. 
France-Ministère de l'Instruction Pullique, des Beaux-Arts et des Cultes. Rapport sur les Observatoires Astrononiques de Province. XXIV, XXIX, XXXI, XXXVII, XLII, LVI, LXII, LXIVII, LXX, LXXI1, LXXIV, LXXVII, IXXXI, IXXXIII, LXXXVII, IC, XCIII. 1887-1906.

Frankford, Pa.-Mistorical Society.

Papers. 11, 2.

Frankfort, A. M.-Deutsche Malukologische Gesetlschatt.

Nachrichtsblatt. XLII, 3-XI.1II, 2. 1910-11.

Senckenbergische Nuturforschende Gesellseha/t.

Ablandlungen. XXII, 1-XXXIII, 3.

Bericlit. I-4. 1910.

Verein fiir Geographie unl Stutistit.

Jahrestericht. LXXIII-LXXIV. 1909-10.

Frankfur, a. O.-Nuturwissentschuflicher Verein.

Itelios. XXVL. 1910.

Monatliche Mitteihngen. II, 7-V1. 1885-87.

Franklin Institute.

JournaI. CLXIX, 3-CIXX1I, 1. 1910-11.

l'maunaneld.-Thurganische Naturforschende Gesellschaft.

Nitteilungen. XIX. 1910.

Frijburg, i. B.-Naturforschende Gesellschaft.

Bericht. XVIII, I. 1910.

Fundono.-Sociêté Fribourgeuise des Sciences.

Bulletins. III, 1883/87 ; 1V, 1887/90; VII, 1893 97-XII, 1903/04 $\mathrm{XIV}, 1905 / 06 \mathrm{XV}-1 \mathrm{I}, 1908 / 09$.

Geneva. L Linstilut National Genevois

Bulletius. XXXVIII-XXXIX. 1909.

Mínoires. $X I X-X X$. 1901-10.

Sociçté de l'hysique et d'llistoire Nuturelle.

Comptes remblus des Séances. IXVII. 19110.

Mẻmuires. XXXVI, 2-XXXVII, 1, 1910-11.

lienos. - Lúluseo Citico di Storia Naturale.

Annali. Ser. 3. 1V. 1908-10.

Gimany.-Tíaiserl. Leopollinisch-Carulinische dentsche Akalemie der Naburforscher.

Abhandlungen. Nova Acta. XC, 2-4; xCI, 3 ; XCII, 1 XCIII, 2.

Leopullina. XLV-XLVI. 1909-10.

Liressen.-Oberhessische (iesellschajt fuir Nutur- und Heilkunde.

Bericht. N. F. Medizinische Abteilung. V. 1909.

Naturwissensclaftiche Alteilung. IJI. 19081909.

Register zon bianden I-XXXIV.

I itasciow. - Nutural Mistory Siociety.

Juйาแ. 1I, 1-1. 15,!/10. 
Grascow.-Glasgow Naturalist. [-H. 1909-10.

R. Philosophical Socinty.

trocedings. XI.I. 1!(09-10.

GOETEnORa.-K. Gesellschaft der Wissenschaftch.

Handlingar. 4 de följ II. 12.1909.

Goettingen.-K. Gesellschaft der. Wissenschaften.

Nachrichten. Geschüftliche Mittcilungen. 1910, 1.

Mathematisch-physikalisclie Klasse. 1908-10.

Philosojhisch-historische Klasse. 19ro, 1-2.

Graz.-Nahuruissensshaftlicher Vercin für Steicrmall.

Mitteilungen. XXVII-XIJIV. 1890-1907.

Great Britain.- Rioyal Photographic Society.

Annual Exlibition. LV. 1910.

Grenoble. - Université.

Annales. XX, 2-3; XXI, 1-3; XXII, 1-3, et supplement;

XXIII, I.

HaArlem.-Musée Teyler.

Archives. Sér. II. XII, 1. 1910.

Société Holtandaise des Sciences.

Archives neierlandaises. Sér. 1I, XV, 1-5, 1910-11.

Teylers Godgeleerd Genootschnp.

Verhandlingen. N. S. XVII.

Hamburg,-Deutsche Seeurate.

Aus dem Archiv. XXXil, 2-XXXIlI, 4, 1909-10.

Ergebnisse der meteorologischen Beobachtungen. 1901-05.

Deutsches incteorologisches Jalırbuch. XXXII. 1909.

Jahresbericht. XXXII. 1910.

Amaleu der IIydrograplie und maritimenMeteorologie. XXXVIII, 4-XXXXX, f. 1910-11.

Nachtrag zum Katalog. IX. 1909-10.

Naturuisenschaflicher Verem.

Abhandlungen. XIX. 3-5.

Verhandlungen XVII. I909.

Harvarl College.-Astronomical Observatory.

Amrals. IJIX, 6; LXV; LXVI; LXVIII, I; LXXI, 1.

Annual Report. LXX. 1910.

Circulars. 15:-155.

Muserem of Uomparative Zonlogy.

Anumal Report. 1909/10.

Bulletins. LII, 15-17; LIII, 5; LIV, 2-5.

Memoirs. XL, 1-2; XLI, 1-2; XXVI, 7; XLV, 1.

Havana. - Colegio de Belen.

Observaciones meteoralógicas y magneticas. 1909.

Harre.-Société Géologique de Normandie.

Bulletin. XXIX. 1909. 
IImidelakra.-Historisch-philosophischer Verein.

Nene Heidellerger Jalnbücher. XVI, 1-2. 1909.

IIrLsingrons.-Societas Scientiarum Fennica.

Acta. XXXV, 1-10; XXXVI, 1-4; XXXVII, 1-2, 4-11; XXXVIII, 1, 3; XXXIX, 4; XL, 1-4, also XIX. 1898.

Bidrag till künnedom af Finlands natur och folk. 52-53, 1893; $67(1-3), 68(1-2), 1910$.

Öfversigt af förlandlingar, VI-VIII, 1863-66; LI, A-C, 1.II,

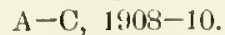

Meteorologisches Jahr]uch. III, 1903 if Supplement.

Ohservations météorologiques. 1899-1900.

1lemannstadt.-Siebentürgischer Verein fiur Naturvissenschaft.

Verhandlnugen und Mitteilungen. IJX. 1909.

Huison Countr, N. J.-Historical Society.

Publications, 1-7. 1908.

I.Lino1s.-State Laboratory of Natural History.

Bulletins. VIII, 4-5 and ludex; 1X, 1-3. 1910.

1NDLA, - 1. Department of Agriculture.

Report on Progress of Agriculture. 1909/10.

Memoirs. Botanical series. I, Index; II, 9; III, 1-6; IV, 1. Chemical series. $1,8-9$.

Agricultural Research Inslitute, Pusa. Report. 1909/10. Bulletin $16,1910$.

Geological Survey.

Memoirs. AXXVI1, 4-XXXVIII, 1910. Palreontologica Indica. Ser. XV. Vol. IV, 2-3; VI, 2; N. S. III, 1.

Records. XXXVIII, 4-XL, 3. 1910.

Meteorological Department.

Annual Summary. 1909.

Nemoirs. XX, 8 and lndex; XXI, 2 .

Mlonthly Weather Review. Dec., 1910 to Feb., 1911.

Rainfall of India. X1X. 1909.

Report of Administration. 1909/10.

Board of Scientific Alvice.

Anmual Report. 1908/9; 1909/10.

Indian Muserm. (Calentta).-Anunal Report. 1907-09.

Catalog'ne of the Indian Decapod Crustucea. I, 2.

Echinojerma. l'art V1, Asteroidea, ”. 1910.

Indians.-Acallemy of Science.

Proceedings. 1909.

Iowa.-State University.

Bulletins. 1aboratory of Natural History. VI, I.

Contribntious. Pliysical I aboratory. I, 4. 1911.

Ireranu. - Pharmaceutical Society.

Calendu. $\mathrm{XXXV} .1911$. 
ItaLY.-R. Comitato Geologico.

Bollettino. 2-3. 1910.

Jamaica Institute.-Journals, I, 1-3; II, 2, 5-1;.

Jenaische Zeilschrift für Naturwissenschaft. XXXIX, 1-X1,2. 1!110-11.

Jolur Crerar Library.

Annual Report. XVI. I910.

Handbook. 1910.

List of Books on the IIistory of Sicience. Jan., 1911.

Johns Hopkins University.-Circulnts, 1910, 4-1911, t.

Kansas. - Universily.

Science Bulletin. V, I-11. 1910.

KaSAN.-Observaloire Mélcorologique.

Bulletins. 1904-09.

Société Physico-Mathématique.

Bulletir. Sér. II, XVI, 3. 1910.

Kuarkofr.-Sociélé des Sciences I'hysico-Chimiques.

Travanx. XXXV1, 1908.

KIEL.-Kommission zur wissenschaftlichen Untersuchung der deutschen Meere.

Wissenschaftliche Meeresuntersnchungen. Abteilung Kiel. N. F. XI-XII.

K. Universität.

Verzeichnis der Vorlesungen. W. 1909/10. S. 1910.

Chronik. 1909/10.

Dissertations.

KiEv.-Sociêté des Naturalistes.

Mémoires. XX, 4-XXI, 2. 1910.

Klausenburo. - Université.

Annales. 1907/08-1908. 1909.

Kodaikanal Observatory.-AnnuaI Report. 1909-I0.

Bulletins. XIX-XXIII. 1910.

Koeniosbero, i. Pr.-Physikalisch-ökonomische Gesellschaft.

Schriften. I. 1909.

Kуото.-I. University. College of Science and Engincering.

Memoirs. II, 1-14; III, 1-3. 1909-11.

La Plata.-Archivos de Pedagogia y Ciencias Afincs. 16-23. 1909-11.

LA Rocaellfi.-Acalémic. Section des Sciences Naturelles.

Annales. 35. 1906/07.

Flore de France. XIV. 1910.

I Aadsanne.-Institut Agricole.

Observations Météorologiques. XVIII, 1904; XXII, 1908.

Société Vaudoise des Sciences Naturelles.

Bulletins. Sér. V, 167-72; also Sèr. II, XI, 66, 68. 1871/73.

LEIDEN. - Nederlandsche Dierkundige Vereeniging.

Aanwinsten der Bibliotheek. I. 1908/09.

Tijdschrift. Ser. II. Deel XI, 3-XII, 2. 
1.ELLN.-Rijksuniversiteit. Sterrewacht.

Verslag. 1908-10.

Leipzia.-K. Sächsische Gesellschaft der Wissenschaften.

Berichte. Mathematisch-physische Ilasse. I.XI, 4-5; LXII, 1-5. 1909-10.

Derein für Erdkunle.

Mitteilungen. 1908-09.

Leriche, Manrice. Les poissons digocènes de la Belgique. Annẻe 1910

L.емпей._Sev̌cenko-Gesellschuft der Wissenschaften.

Chronik. 11, 38; 111, 39; IV, 40. 1909.

Sammelschuift. Muthematisch - Naturwissenschartlich-Artliche Section. VII, 1; 1X; XIV.

Lıtian.-Sociétê Li. des Sciences.

Mémoires. VIII. 1909.

Lınвura.-Provinciaal Genootschap voor Geschiedkundige Wetenschappen, 'iuat en hunst.

limburg's Jaarboek. XVI, 4; XVII. 1910-11.

Linz.-Mrusezm Francisco-Carolinum.

Jahresbericht. 69.

1.ISBon,-Sociedade de Geographia.

Boletim. Ser. XXV11I, 1-12; XXIX, 1-3. 1910-11.

Laverrool.-Geographical Society.

Transactions and Anuual Report. XVIII-XIX. 1909-10.

L.ONDON.-Bioloyical Society.

Proceedings. XXIV. 1909/10.

K. Geographical Society.

Geographical Jourual. XXXV, 3-XXXVII, 5. 1910-11.

Geological Society.

Quarterly Journal. 261-65. 1910-11.

Geological Literature added to Library. 1909.

Linnaean Suciety.

Journal. Botany. 272. 1909. Zoology. 201, 202, 207. 1910.

I.ist. $1910 / 11$.

Proceediugs. 122. 1909-10.

Mathematicul Society.

Proceedings. VIII, 3-7; IX, 1-7. 1910-11.

R. Microscopical Society.

Journal. J910, 1-1911, 3.

National I'tysical Laboratory.

Annual Report. $1905,1910$.

Collected Researches. VI-VII. 1910-11.

Patent Office.

Catalogue of Jibrary. I. Authors. 1899.

library series. 1-2, 4-18. 1905-07.

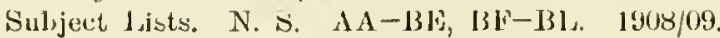


L LONDON.-Royal Shcicty.

Plilosophical'l'musactions. Ser. A.161-76. Ser. B.273-81. 1910-11.

Procedings. Sees. $\Lambda$. 5ij3-79. Ser. 13. 555-1;8. 1910-11.

1.ovistana. - Statc Museum.

Natural llistory Survey. Bulletin. I. 1911.

Lenendna. - Naturuissenschaftlicher Verein.

Jalireshefte. XV1II. 1908/10.

LUND.- K. Universitct.

Acta. N. F. V, 1-y, 1909; leegister. 184:1-190t.

Biblioleks Årsberättelse. 1909.

Loxembovre,-Institut Grand-Ducal.

Section des scienres naturelles, physiques et mathématiques. Archives trimestriclles. N. S. $1 \mathrm{~V}, 1-\mathrm{V}, 1.1909-10$.

Lyons.-Acarlémie des Seiences.

Mémoires. Śér. III, 11. 1911.

Sociêté il'agrieulture, Seiences et Industrie.

Anuales. 1909.

Université.

Annales. Science-Médecine. N. S. 1, B, 25-29. 1899-1909.

Annales. Droit-Lettres. N. S. 11, 4, 21, 22. 1900-1910.

Sociéte des amis de l'Université. Bulletins. XXI1I, 1-XXIV, 1, 1910-11.

Bulletin Hislorique thu Diocise de Lyon. I, b; II, 2. 1909. 1911. Madras.-Fisheries Bureau.

Bulletins. $4-5$.

Madrid.-R. Academia de Ciencias Exactas, Fisicas y Naturales.

Memorias. XV.

Revista. VIII, 7-1X, 8.

Comision del Mapa Geológico.

Boletin. X-XI. 1908/09.

Observatorio.

Anuario. 1911.

Resumen de las Observaciones Meteorologicas. 1902-05.

Mastebura.-Nuseum fïr Nutur- und Ileimatkunde.

A bhandlungen und Berichte. II, 1. 1910.

Maine Agricultural Experiment Station.

Bulletin. 190. 1911.

Manchester, England-Gcographical Socicty.

Journal. XXV, 2-XXV1, 2. 1\$09-10.

Litcrary and Ihilosoplical Society.

Memoirs and Proceedings. LIV , 2-LV, 1. 1909-11.

Muserem.

Publications. $67-71,1910$.

University.

Publications. Ilistorical Series. 1X-XI. 1911. Medical Series. X11I. 1911. 
Mannhein. - Verein fïr Naturlunde.

Jahresbericht. 75. 1910.

Marbura.-Gesellschaft zur Beforderning der gesamiten Nuturwissenschaften. Sclurifteı. X, 2-1, $(;-7,10,12 ; x I 1,1-7 ; X I 1], 1-6$.

Sitzungsberichte. $1909-10$.

M Ecklenino.-Verein der fresnde der Naturgeschichte.

Archiv. 1 XXIII, 2-IXIV. 1909-10.

Melbovine.-National Musezm.

Memoir. 3. 1910.

Mexico.-Instituto Geológico.

Boletin. 25, 27. 1910.

Parergones. I11, 3-8. 1549-10.

Instituto Melieo Nacional.

Anales. July, 1908 to Feb., 1909 and Nach to April, 1910.

Observatorio Meteorologicu Magnetico Central.

Boletin. Mity, 1909 to 1)ec, 1909; Feb. to June, 1910.

Sociedlud Cientifica "Antonio Alzate".

Memorius y Revista. XXVII, 4-XXVIII, 8.

Hiongan.-Academy of Sciences.

Report. Fll. 1910.

Midieliburo.-Zeenusch Genootschap der II'tenschappen.

Archiel. 1910.

Malan.-1i. Istituto Lombardo di Scienze e Iettere.

Rendiconti. Ser. 11. XLII, 16-20, XLII, 16. 1910.

R. Osservutorio Astronomico di Brera.

Pubiblicazioni. X'VVII. 1910.

Socitta Ituliana di Scienze Naturali e del Mreseo Civico.

Atti. XLVIII, 4-L, 1. 1910-11.

MnwaUke. - Public Museum.

Anmul Report. XXVII-XXXVIII. 1909-10.

Bulletin. I, 1.

Minnesota. - Geological and Natural History Survey.

BotanicaI Series. Report of Survey. V.

Botanical Stndies. IV, I, VIII; Ser. 11, 1-6; Ser. III, 1-3.

Plant Studies. 1-IV.

Bulletins. 1, 2, 5, 8, 10.

Zoological Scries. $11-1 \mathrm{~V}$.

Missoura.-Botunical Garden.

Annun! Report. XXI. 1910.

Monena.- $R$. Acculemia di Scienze, Lettere ed Arti.

Memoric. Ser. I1, T. XII, 1, 1896; Ser. III, 'T. VIII. 1910.

Societa dei Naturalisti e Matematici.

Anmario. II-VI, VII, 2-4, XII, 3-4, Ser. 11, '1. XIV.

Atti. Rendiconti. Șer. 111, 'T. V11, 2; Ser. IV, T. III, 1-2, VI, XI and XI1. 
Montana.-Agricultural Eaperiment Station (Bozeman).

Ammal Report. XVI. 1909.

Bulletins. 77-80, 82-83, 85. 19:01-11.

College of Agriculturc and Mechanicul Arts.

Experinent Station Circular. 4. 1910.

Univcrsity of Montana.

Bulletin. 68. 1910.

Montevide. - Museo Nacional.

Aniles. IV, 1-2. 1910; also Ser. 11, 'I' J, 3.

Observatorio Nacional Fisico-Climatologico.

Boletin. 79-81. 1909.

Montpeluer.-Académie des Sciences et Lettres.

Bulletin Mensual. 1910, 4-7; 1911, 1-4.

Mémoires de la Section de Méderine. Sér. II, T. I1I.

Mémoires de la Section des Sciences. Sér. II, T. IV, 1-2, V, 2.

Moscow.-Sociêté 1. des Naturalistes.

Bulletius. 1908, 3-1909. N. S. XXIIJ.

MÜNSTER i. W. - West fälischer Provinzial-Verein fï W'issenschaft und Tunst.

Jaliresbericht. XXXVIII. 1909-10.

Munich. $-K$. Bayerische Akademie der llissenschaften.

Ahliandlungen. Mathematisch-physikalische Klasse. XXIV, il ;

XXV, 1-4. 1909-10. Supplement-Bünde. I, 7-10; II, 2; I1I, $1 ; 1 \mathrm{~V}, 1-2$.

Sitzungsbericlıte. Mathematisch-physikalische Klasse. 1909. Abhandlung. 1909, 15-1910, 9.

Philosophisch-philologisch und historische Klasse. 1909. Ablandlung. 1909. 7-9. 1910. $1-6$.

Nancy.-Acalémie de Stanisles.

Mémoires. Sër. VI. 'T. VI-VII. 1908-10.

NAPLES. $-R$. Instituto d'Tncoraggiamento.

Atti. Ser. VI. 'T. LX-LXI. 1908-09.

R. Accademia dolle Scienze Fisiche e Matematichc.

Atti. Ser. II, 'T. XIV.

Rendiconti. Ser. III. T. XV, 8-XVI, 12. 1910; also supplement 189.

12. Accademia di Scienze Morali e Politiche.

Atti. XXXIX-XIs. 1910.

Rendiconti. XI,V1II-XLIX. 1909-10.

R. Università.

Museo Zoologico. Annuario. N. S. III, 1-12. 1910.

Natal.-Government Museum.

Annals. II, 2, 1911.

Naturae Novilatcs. 1910,3 to 1911, 7.

Neuchatel. - Académie Faculté des Leltrrs.

Recueil des Travaux. V. 1910. 
Nevonatel. - Société Nenchateloise des Sciences Nąturetles.

Bulletins. XXXV-XXXVII. 1907-10.

New South WaLs. - Limean Society.

Proceedings. No. 135-8. 1909-10.

New York.-Acalemy of Sciences.

Annals. X1X, 2-XX, 2; XX1, pp. 1-86. 1910-11.

Botanical Garden.

Bulletins. VI, 21-22; VIT, 25. 1910-11.

Public Iibrury.

Bulletins. XIV, $4-\mathrm{XV}, 6.1910-11$.

State Museum.

Memoirs. XI1, 1; XIII. $1909-10$

NEW Zealan1). - Institute.

Transactions and Proceedings. XLII. N. S. 1911).

NeWCastLe-UPON-'I'YNE. - North of England Institute of Mining and Mechanical

- Engineers.

'Transactions. LX, 1-9; 1,XI, 1-4. 1910-11.

Anuual Report. 1909/10.

Norfolk and Norwich Naturalists' Society.

'T'ransactions. 1X, 1. 1910.

North Carolina. - University.

Philological Club. Studies in Philology. V-V11. 1910-11.

NonTh Dakota.-University.

Quarterly Jourual. I, 1-4. 1910/11.

Sehool of Mines Bulletin. N. S. I, 2, 6. 1909

North Stuffordshire Field Chul.

Annual Teport and 'T'ansactions. XlLIV-XI.V. 1909-10. $1910-11$.

Northamptonshire Natural History Society anul Field Chl.

Joumal. XV, 117-2.J. 1909-10.

Northumbertand, Durham and Newcastle-upon-Tyne, Natural History Socitiy.

T'runsactions. 1, 1-3; 1I. N. S. 111, 1-2. 1511.

Nova Scotia.-Department of Mines.

Report. 1910.

Nova Scotian Institute of Science.

Procedings and Transactions. X1, 3-1; XII, ?. 1904-8.

Nunenbera. - Naturhistorische Gesellschaft.

Ablandlungen. VIII; XV, 1-3; XVIII.

Onessa.-Observeture Mitéorologiqne et Mhgnitique.

Antuatise. 1908-04.

Онио.-State Acudemy of Science.

Proceedings. V, 6. 1910.

Geological Survey.

Bulletins. 10-12. 19th-10.

Onianoma.-Geological Survey.

Bulletius. 2, 5, 6. 1911 . 
OKLahoma. State University.

liescardi Bulletins. 3-4. 1910.

Оровто.-Acatemia Polytechnica.

Anunes Scienllficus, 111, is-V, 4. 1910-11.

Oxforn.--liadctiffe Library.

Catalogue of boeks added during 1910.

University Observatory.

Astrographic Catalogue. V-VI. 1910.

Paedologisches Jaarbock. I, 1900 ; VI-VII. 1909-09.

Palerso.--Societì di Scienze Naturali ed Economiche.

Gionale di Scienze Naturali ed Economiche. XXY1ll. 1911.

Parts.-Ecole Polytechnique.

Journal. 2e Sér. XIII-XIV. 1910-11.

Ecole Normale Supcrieure.

Anuales. XI.V, 1-XLVIII, 6. 1908-11.

Muséum d'Histoire Nahurelle.

Bulletins. 1909,$8 ; 1910,1-5$.

Laboratoire de l'hanérogamie. Notulue Systematirne, par 11. Leromte. 'T. I-11, 2. 1909-11.

Observatoire.

Rapport Amuuel. 1909-10.

Socićté Zoologique de France.

Bulletins. XVII, 1, 8; XXXIV.

Mémoires. XX1I. 1909.

Pasaidena. - Throop lustitule.

Bulletins. 46-50. 1910-11.

Pathologica: Revista Quindicinale. II. 36-44. 1510.

Pero.-Ministerio de Fomenlo.

Cuerpo de Ingenieros de Minas. Boletin. 75-76. 1910.

Philadelrita.-Academy of Natural Sciences.

Journal. XIV, 2.

Geographical Society.

Bulletins. VIII, 2-1X, 2. 1910-11.

Wagner liree Institule.

Transactions. VJl. 1910.

Thotographic Journal, London. L, 2-J,I, 6 and supplement to 5. 1910-11.

PIsa.-Socictí Toscana di Scienze Naturabi.

Atti. Memorie. XXV. 1910.

Processi Vertali. XIX, 2-5; XX, 1. 1910-11.

Pittsburoh.-C'nnegie Librury.

Aunual Reports. V-VIII, X11I-XIV. 1901-4, 1:109-10.

Carnegie Museum.

Memoirs. IV, 2, 5-6.

Publications. 60, 61, 683, 66 .

PorsDax.-Astrophysiknlisches Observatorium.

Publikationen. XX-XXII, 1. 1910-11. 
Putsdan.-Photograjhisclıe Himnelskarte. V, 1910.

Praо.-K. K. Böhmische Gesellsehaft der lVissenschatten.

Jahresbericht. 1909, 1910.

Sitzungsberichte. 1909, 1910.

Českẻ śpolečnosti Entonologické. Časopis. VII, 1-VIII, 1. 1910-11.

Deutscher Natmwissenschaflich-medizinischer. Terein für Böhnen.

Lotos. LVII-I.V111. 1909-10.

T. . S. Stermarte.

Magnetische und meteorologische Beobnchtungen. 1909.

Providence,-Fioger W'illiams l'ark Museum.

Bulletins. 7-8.

Monograples. 14, 15, 17 .

quebec.-Literary and IIistoricel Society.

Transactions. $\quad \mathrm{T}, 1 ; 1900-1902 . \quad$ No. 21.

Provinee.

Gilides. $1909-10$

Société de Tréographie.

Bulletins. IV, 1-V, 3. 1!110-11.

Regensbuno.-Historischer Verein von Oberpfalz und Regensburg.

Bericht. VTI. 1907-04.

Verbandlungen. IXXI. 1909.

Zoologiseh-Mineralogischer Verein.

Abhandlungen. Ilette 1, 3,5, 7-9. 1819-64.

Répertoire d'Art et d'Arehéolugie. Année I, 1-1. 1910.

Riga.-Naturforscher-Ierein.

Arbeiten. N. F. XII. 1910.

Korrespondenzblatt. LIII. 1910.

Rio de Jankiro.-Instituto Osicaldo Cruz.

Memoria. 11, 1-?, 1910.

Rockefeller Institute of Medical Researeh.

stuclies. X-ẌII.

Roentgen Society. Journal. VI, 23-VII, 27. 1910-11.

Rode. $-R$. Aceadenia dei Lineei.

Atti. Serie V. Rendiconti. Classe di Scienze fisiche, matematiche e naturali. XIX, 6-XX, 10. 1910-11.

Rendiconto dell'adunanza soleme, 1910, II.

Aecalemia Pontifica Romana dei Nruovi Lincei.

Atti. LII, 1-2; LXIII, 1-7. 1909/10.

ir. Louls. - Academy of Scienees.

Transactions. XVIII, 6 ; XIX, 2-11; XX, 1-3.

Str. Peterseoura.-Académie 1 . des ściences.

Bulletins. Classe Plıys.-Matlı. Sér. V, 1898, 5 ; Sèr. VI, 1910, 6 $1911,11$.

Minnires. Classe Plıys.-Muth. Sid. VIII, V, 3, T. XVIII, 9, 1t, 15; XXI, 1; XXIV. 1, 2, -1-10; XXV, 1-8. 
St. Petersbouro.-Mémoires. Classe Hist.-Phil. Sér. VIII, T. III, 1; VII, 1-2; VIII, 13-14.

I. Botanic Garden.

Aeta. XXVI, 2; XXVII, 3; XXVIII, :3.

Comité Géologique.

Bulletins. XXVIII-XXIX, 4. 1908-10.

Mẻmoires. N. S. 40, 5I-2, 56-7, 59. 1908-10.

I. Russian Geographical Socicty.

Bulletins. XIV, 1-9; XLV1, 1-5. 1909-10.

Report. 1909.

Santiago de Chule.-Dentscher Naturwissenschafticher Terein.

Verhandiungen. V, 1-2; VI, 1.

Sociedad Cicutifica de Chile.

Actes. XIX. 1909.

São Pavlo.-Sociedad Scientifica.

Revista. Jan., 1909 to Aug., 1910.

Schweizerische Naturforschende Gesellschaft.

Verhandlungeu. XCII-XC11I. 1909-10.

SHARP, D.-Fanena Havaiicnsis. II, part. III ; 11I, part VI.

Siena.-R. Accalemia dei Fisiocratici.

Atti. Ser. IV, II, 1-1;.

Smithsonian Institution.

National Museum. Bulletins, 39, 71-4.

Contributions from National Herbarium. XIII, 3-9; XIV, I-2; XV.

Proceedings. XXXVII-XXXVIII. 1911. Report. 1910.

Bureau of American Ethnology. Bulletins. 37, 43, 45, 49-50.

Società Entomologica Italiana.

Bulletins. XI.I, 1-4. 1909.

Soutin Arrica. - Moyml Socicty.

Transactions. 11, 1-2, 1910-11, and Index.

South-Eastern Union of Scientific Societies (Woking).

South-Eastern Natualist. 1910.

Soulh London Fintomotogical and Natural History Society.

Proceediugs. 1909-10; 1910-11.

Staten Island Association of Arts and Sciences.

Proceedings. III, 1-2.

Staten Island, N. Y.-Natural Science Association.

Proceedings. 11, 3-4.

Sтоскноцм. - K. Svenska Vetenskaps-Academi.

Arkiv för Botanik. IX, 2-X, 1.

Arkiv för Kemi, Mineralogi oclı Geologi. III, 4-6; IV, 1. 
Sтоскноцм.-Arkiv för Matematik, Astronomi och Fysik. VI, 1-3. Arkiv för Zoologi. VI, $1-4$; VII, 1.

Arsbok. 1910.

Handlingar. XI, V, 3-XLVI, 3.

Meteorologiskn falsttagelser. L, Append., I.I.

Les Prix Nolvel; 907-8

K. Billiothek.

Accessions-Katalog. 23. 1908.

Entomoloyisk Förening.

Lintonologisk 'Jidskrilt. XXSI, 1-4, 1'111).

Forstliche Versuchsanstalt.

Meddelanden. 7. 1910.

StrutradrT. - Verein für Vuterländische Naturkunle in Württemberg.

dalureshefte. 1910, 1.

Sronkx. - Australiun Musetm.

Memoir. $1 \mathrm{~V}, 12$.

Report. INI. IOI0.

Special Catalogue. No. I, Vol. III, pt. I.

Tasmania.-Royal Society.

Papers and Proveetings. 1:109.

'Twxas.-University.

Bulletins. 129, 134-8, 140,142-3,145-6, 152-3,161; -7, 170, 178.

'Truts.-Physikalisches Observatorium.

Beobnchtungen. 1899-1504.

Seismische Mlonatslierichite. 1909. 1-7.

'Токхо. - Deutsche Gesellschuft für Natur- und Völkerhunde Osfusiens.

Mitteilungen. XII, 2. 19I0; also XI, 2. 1908.

l'niversity.

Journal of the College of Sicience. XXVIl, 7-20, XXXVII, 1-6.

Calendar: $1909-10$.

'Toronto.-Canadian Institute.

Proceedings. II, no. 12, part 6.

Transictions. V111, no. 19, part $t$.

University.

Publications. Biological Series. 8.

tieolugical Series. $6-7$.

'Tourousk.-Acalémie des Súciences.

Mimoires. Sèr. X. T. IX.

Université.

Faculté des Sciences. Ammales. Sẻr. I , T. X, 3-t; Sér. III, 'T. I, 1, 3.

Bibliothèque Méridionale. Ser. I, T, 1, 4 Xfll, XIT; Síl. If, 'T. HII, VII]-X, XII-XII]. 
Tovounse-Annuaire. 1894-1900.

Bulletins. 13, 1-2.

Observetoire Astronomique, Magnitique et Méturologique.

Anumles. VI. 1907.

Société d'Histoive Naturelle.

Bulletins Trimestr. XLII, 3-4; XL111, 2-"?.

T'uEst.-Osservatorio Maritimo.

Rapporto Anuuale. 1966.

'T'romsoF. - Museum.

Aarsberetning. 1908-09.

Aarshefter. $30-32 . \quad 1907-09$.

Geologiske Undersogelser. IV, Pettersen.

'Tronunem. - K. Norske Videnskubers Selskiab.

Skrifter. 1872, I ; 1874, I-1I; 1909.

Tufts College.

Studies. Scientific Series. III, 1.

I'Urin.-Musei di Zoologic ed Anatomia Comparata.

Bolletini. XXV1, 616-33 and index.

Uniten States.-Department of Agriculture.

Crop Reporter. 1910, 5-10.

Library. Bulletins. $46-53$.

Montlyly Bulletins. I, 3-1I, 4.

Division of Publication. No. 713.

Weather Bureau. Mt. Weather Observatory. Bulletins. II, 4-111, 5 and Index. 1910.

Department of the Interior.

Geological Survey. Annual Report. XXXI. 1310.

Bulletins. $323-4,328,337,343,361,364-8$, $370,381-2,385-6,398,406-7,415,417$, $419-20,422,425-30,432-47,453,465$.

Geologic $\Lambda$ tlas. Folios 167-176.

I'rofessional Papers. fi8.

Water Supply and 1rrigation Paper's. 237, $239,241,243-55,260,262,264$.

Library of Congress.

Outline Scheme of Clisses (preliminary), Dec., 1900.

Publications issued since 1897, Jan., 1911.

Reprort of Librarian. 1910.

Naval Observatory.

Publications. 2 d Ser., VI-VII. 1911.

Superintendent. Synopsis of Report. 1910.

Upsaba.-K. Universitet.

Arsskrift. 1909 .

Genlogiska Lustitution. Bulletins. IX, 17-20, 1908-11; and Index, $1-X$. 
IJTRech'T. - K. Nederlundsch Meterolngisch Institunt.

Anmuaire. 1909, A-B.

Mededeelingen en Verhandlingen. 102 (10-11), 1910/11.

Frovincial Utrechtsch Genootschap ran hiunsten en Vetenschappen.

Aateekeningen van het Verhandelde in de Sectie-Vergarleringen 1910.

Verslag van het Verhandelde. 1910.

l'auderbilt Southern Histury Society.

Pnblications. 1.

V'underbilt Iariversity.

Oriental series. VI-VII. 1908-10.

Vienna. - K. Kr. Akudemie der Wissenschaften.

Eralbeben-Konnission. Bericht nnt Chronik. V. 1910.

Mitteilungen. XXXVII. 1909.

Sitzungsherichte. Mathemal.-nutnwiss. Kilasse. CXV]II, 8CXIX, Abt. 111, 5.

h. K. Central-sustalt fitr Meterologie und Freolynamik.

dahdiacher. N. F. XILII-XI,V.

K. K. Geolugische lieichsanstalt.

Abrandlungen. XVI, 3; XX, 3; XXII, 1.

Jahlbücher. $1 \mathrm{X}, 1-3.1910$.

Verhandlungen. 18:4; (1:3-15); 1903 (1); 1909 (15-18); 1910 $(1-18)$.

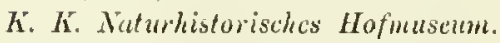

Amnalen. XX1]I, 4-XXIV, 2. 1909-10.

Verein zur J'erbreitung Naturwissenschafllicher lienutnisse in Wien. Schriften. L.

K. Ir. Zootogisch-Butuische Gesellschaft.

Verhandlungen. LIX, IX. 1909-10.

Virginia, Lnicersity of:

Philosoplical Society. Publications. Bulletins. I, 1-4. 1910.

Humanistic Series. I, 1. 1911.

Scientifie Series. I, 1-5, 1910-11.

Warrin, Pa.-Acudemy of Sciences.

Transations. I, 2. $1908 / 09$.

II'estern Penusyl'ania E'nginecr's' Society.

Proceedings. XXVI, 4-XXV]1, 5. 1910-11.

WIEsBalen. - Nassunischer Vercin für Naturkunde.

Jalurbuch. 6is. 1:110.

Hilson Ornithological Club, Uberliu, O.

Wilson Bulletins. 70-1, 1910-11; also XXI11, 2; Indices to $\mathrm{XXI-XX11.}$

Wisconsin Geological and Natural IIistory society.

Bulletins. XIX-XXII.

Road Pamplitel. 5. 
IVisconsin Natural History Society.

Bnllotins. N. S. VII, 3-4, VIII, 4-IX, 2. 1919-11.

Occosiomal Prpreis. I, 1, 3, II, 1-3, $11 \mathrm{I}$.

Wurznuna. - Mysikalisch-medizinische Gesellschaft.

Sitzungs-Berichte. $1909,1-5 ; 1910,1-5$.

Wyoming Historical and Geological Society.

Proceedings and Collections. XI. 1910.

Ialc University.

Astronomical Observatory. 'Transnctions. II, 2. 1910.

ZÜRI'H.-Naturforschende Gesellschaft.

Vierteljahrsschrift. LIV, 3-IV, 2. 1909-10. 




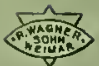




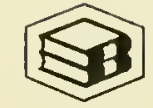

This preservation copy was printed and bound at

Bridgeport National Bindery, Inc., in compliance with U.S. copyright law.

The paper used meets the requirements of ANSI/NISO Z39.48-1992

(Permanence of Paper).

P B

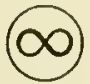

1997 






DATE DUE

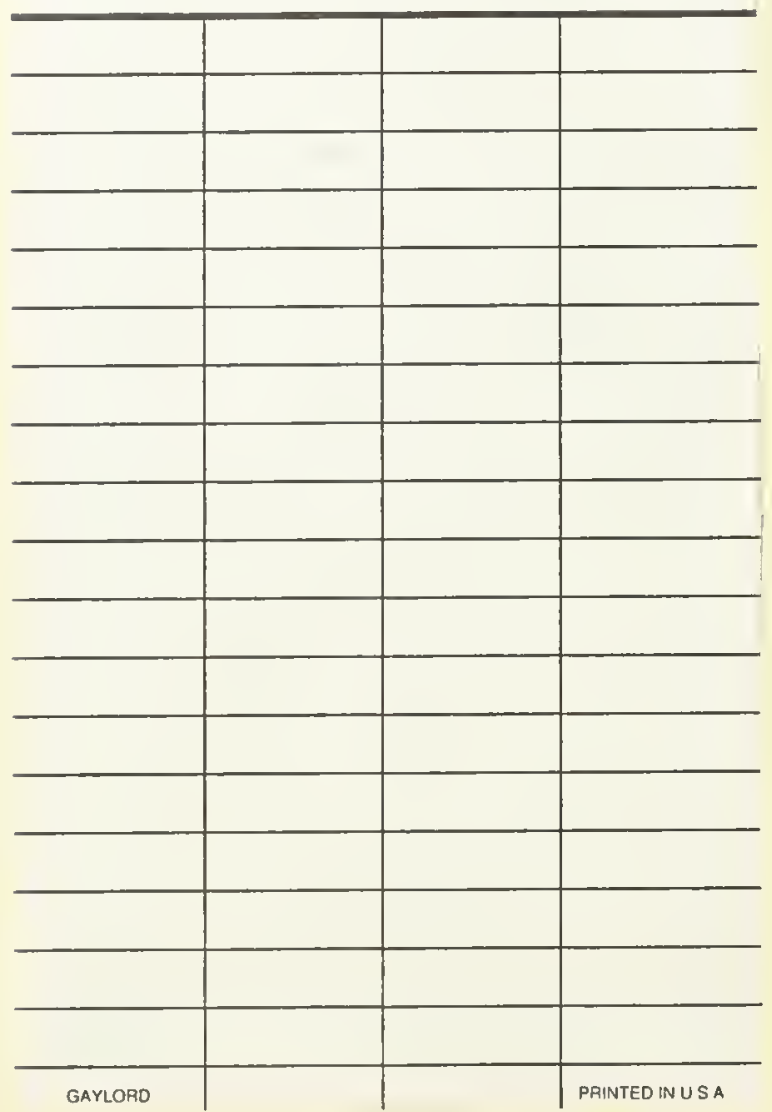




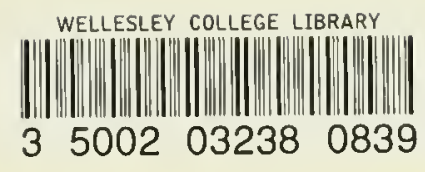

Sctence Q 11.C9 16:2 1911a

Emerton, J. H. 1847-1930.

New spiders from New England 
